\title{
Subsidies with Export Share Requirements in China*
}

\author{
Fabrice Defever ${ }^{\dagger}$, Alejandro Riaño ${ }^{\ddagger}$
}

December 14, 2016

\begin{abstract}
A subsidy is subject to an export share requirement (ESR) when firms must export more than a certain share of their output to receive it. Such incentives are frequently found in free trade zones, export processing regimes and measures targeted at foreign investors, both in China and other developing countries. In this paper we provide the first quantitative assessment of the effect that using subsidies with ESR has on exports, the intensity of competition and welfare, both in the enacting country and its trading partners, using a two-country model of trade with heterogeneous firms. We find that the subsidy with ESR boosts exports more than an equivalent unconditional subsidy available to all exporters. Crucially, the subsidy with ESR provides greater protection to low-profitability firms, while the unconditional subsidy does the opposite. The combination of export promotion and lower intensity of domestic competition generated by the subsidy with ESR can be described as "protectionism through exporting." The imposition of an ESR, however, greatly exacerbates the welfare loss associated with subsidizing exporters.
\end{abstract}

Keywords: Export Share Requirements; Export Subsidies; Export Intensity; Free Trade Zones; Export Processing Regimes; China.

JEL classification: F12, F13, O47.

${ }^{*}$ We thank Nathan Nunn (the editor) and two anonymous referees for their helpful comments and suggestions. We thank Daniel Bernhofen, Arnaud Costinot, Kerem Coşar, Ron Davies, Klaus Desmet, Jason Garred, Eugenia Gonzalez, James Harrigan, Kala Krishna, Giovanni Maggi, Petros Mavroidis, John Morrow, Doug Nelson, Emanuel Ornelas, Veronica Rappoport, Luca Rubini, Michele Ruta, Tim Schmidt-Eisenlohr, Christian Volpe-Martincus, Fabrizio Zilibotti and participants at the May 2012 GEP Workshop on International Trade, the June 2012 CAGE-CEP Workshop on Trade Policy in a Globalized World, the CEPII-GEP-Ifo Conference on China and the World Economy, ETSG 2013, the Fall 2012 Midwest International Trade Meetings, the 6th FIW Research Conference in International Economics, the 2013 Royal Economic Society meetings, the 2013 FREIT meetings in Izola, the CESifo-Delphi Conference on the Economics of Firm Exporting, the 2013 China Economics Summer Institute and the 2015 Meetings of the American Economic Association for helpful comments. We thank Zheng Wang and Zhihong Yu for providing the firms' name concordance table between the NBS manufacturing survey and the customs data. We thank Helen Durrant for editorial assistance. This paper has been previously circulated with the title "China's Pure Exporter Subsidies" All remaining errors are our own.

${ }^{\dagger}$ City University of London, GEP, CESifo and CEP/LSE. fabrice.defever@city.ac.uk

${ }^{\ddagger}$ University of Nottingham, GEP, CFCM and CESifo. alejandro.riano@nottingham.ac.uk 


\section{Introduction}

China's ascent to become the world's largest exporter has been nothing short of spectacular, and has naturally attracted considerable attention among economists and policymakers alike. ${ }^{1}$ Although China's strong reliance on subsidies to promote exports is well established, the fact that several of these policy measures are subject to export share requirements (ESR) - i.e. they are only available to firms that export more than a certain share of their output — has so far been overlooked. ${ }^{2}$ Thus, our objective in this paper is to shed light on the effects of using subsidies with ESR on a country's exports, intensity of competition and welfare from a quantitative standpoint.

Understanding the implications of imposing ESR on subsidies is of paramount importance for two key reasons: firstly, trade policy instruments featuring export requirements such as export processing zones and duty drawback schemes are widely popular not only in China, but also across a large number of developing countries. ${ }^{3}$ Secondly, as we show in the paper, making a subsidy subject to an ESR engenders substantial distortions over and above those caused by an equivalent unconditional subsidy granted to all exporters.

There is a wide range of policy measures such as direct cash transfers, tax holidays and deductions, and the provision of utilities at below-market rates that are subject to ESR in China. For instance, the 2004 Transitional Review Mechanism conducted by the World Trade Organization (WTO) on subsidy practices in China noted that firms located in several special economic zones and exporting at least $50 \%$ of their production enjoyed tax deductions, access to soft loans and priority access to infrastructure and land. The same document also stated that firms exporting more than $70 \%$ of their output benefitted from local income tax exemptions and a reduction in their corporate income tax rate. ${ }^{4}$ Another example is the restriction faced by foreign firms until 2002, which forbade them to produce a wide range of consumer goods (e.g. digital watches, bikes,

\footnotetext{
${ }^{1}$ See e.g. Naughton (2007), Branstetter and Lardy (2008), Feenstra and Wei (2010), Rodrik (2010), Song et al. (2011), Hanson (2012), World Bank (2013), among many others.

${ }^{2}$ Naughton (1996) and Feenstra (1998) are exceptions; they however, only offer anecdotal evidence documenting the use of these subsidies in China.

${ }^{3}$ Table 1 lists twelve large countries (i.e. with population above 30 million inhabitants) that offer subsidies with ESR according to the U.S. State Department's Investment Climate Statements. Additionally, 19 small developing countries were required to eliminate incentive programmes subject to ESR by December 2015 in order to comply with disciplines in the Agreement on Subsidies and Countervailing Measures of the WTO (Creskoff and Walkenhorst, 2009; Waters, 2013; World Bank, 2014).

${ }^{4}$ Questions by the European Communities with regard to China's Transitional Review Mechanism on Subsidies and Countervailing Measures, September 30, 2003 (references G/SCM/Q2/CHN/5 and G/SCM/Q2/CHN/7).
} 
washing machines and refrigerators) unless their exports accounted for more than $70 \%$ of their production. Similar restrictions have only been lifted in 2013 for the domestic sale of video game consoles such as Nintendo's Wii and Sony's Playstation, which have been manufactured in China for more than a decade. ${ }^{5}$

The large number of exporters in China that are eligible to benefit from subsidies with ESR based on their export intensity is staggering. Figure 1 presents the distribution of export intensity — the share of total sales accounted for by exports - for Chinese manufacturing exporters between 2000 and 2006. Half of all exporting firms in China sell more than $70 \%$ of their output abroad, and half of these in turn, are "pure" exporters, i.e. firms selling all their output abroad. ${ }^{6}$ In contrast, Bernard et al. (2003) and Eaton et al. (2011) report a negligible share of high-intensity exporters in the U.S. and France respectively. ${ }^{7}$ It is also notable that none of the workhorse models of trade with heterogenous firms such as Melitz (2003), Melitz and Ottaviano (2008) or Arkolakis (2010) can easily reproduce such a heavy right tail of the export intensity distribution. Figure 1 suggests that the availability of subsidies with ESR in China could affect substantially the distribution of export intensity.

We investigate the consequences of subsidies subject to ESR in the context of a two-country model of trade in which firms are heterogeneous in their productivity as in Melitz (2003), but also in terms of firm-destination-specific demand shifters as in Eaton et al. (2011). ${ }^{8}$ Thus, in the absence of subsidies, each exporter in our model has a unique optimal export intensity — which we call "natural" export intensity — determined both by aggregate variables such as a country's expenditure and price index, transport costs and idiosyncratic demand shifters. Since we also assume that the fixed costs associated with operating in a given market are destination-specific, it follows that our model produces both "regular" exporters, i.e. firms that sell both in the domestic market and export, as well as pure exporters. In contrast, in the workhorse Melitz (2003) model, all exporters in a given country sell some of their output domestically and have the same export intensity.

\footnotetext{
${ }^{5}$ See: http://www.reuters.com/article/2014/01/07/us-china-gamesconsoles-idUSBREA0606C20140107.

${ }^{6}$ The pervasiveness and distinct features of high-intensity exporters in China have also been studied by Lu (2010), Dai et al. (2016) and Lu et al. (2014).

${ }^{7}$ More precisely, only $0.7 \%$ of U.S. exporters display an export intensity greater than $90 \%$. Using data from the Enquete Annuelle Entreprises, SESSI, for the year 2000, we find that the corresponding figure for France is $1.9 \%$.

${ }^{8}$ Other models that feature firm-destination heterogeneity in demand are Bernard et al. (2011), Crozet et al. (2012) and Cherkashin et al. (2015).
} 
Figure 1: Export Intensity Distribution of Chinese Manufacturing Exporters, 2000-2006

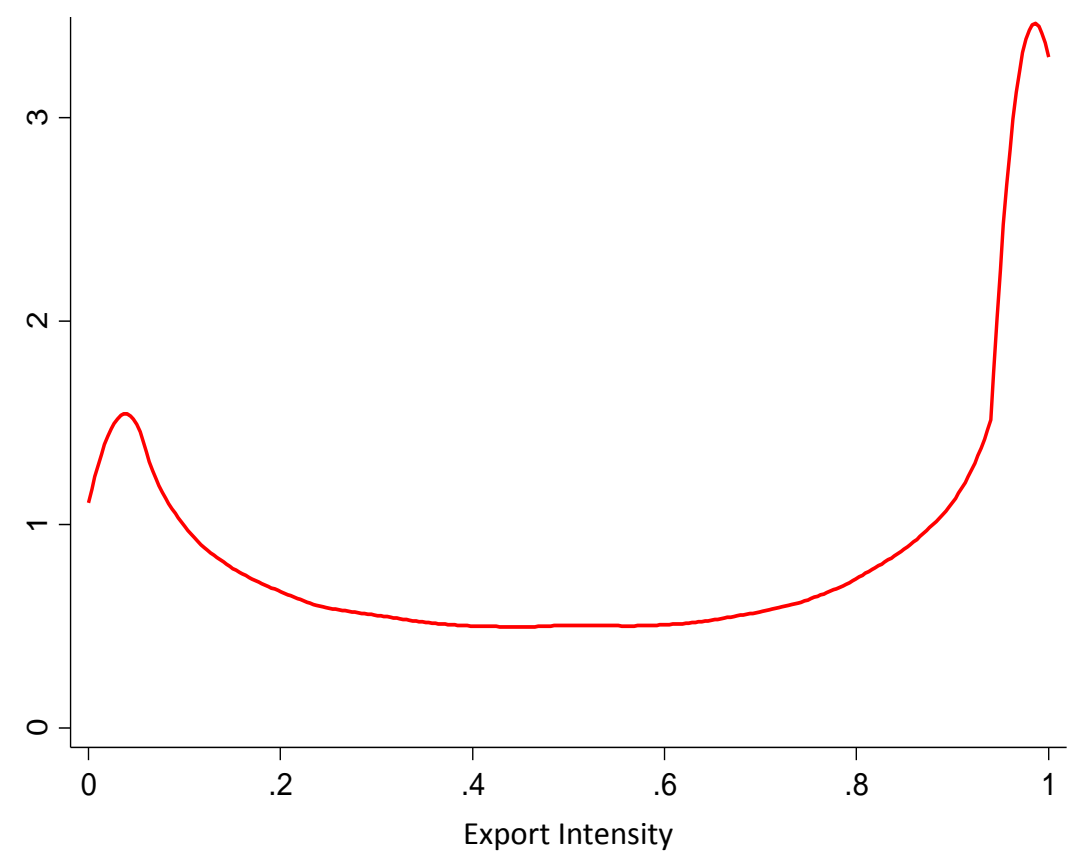

The figure depicts the kernel density of export intensity - defined as the share of exports in total sales - for Chinese manufacturing firms reporting a positive value of exports. Data are for the period 2000-2006 and are described in detail in Appendix A.

Heterogeneity in firms' demand across different markets is a crucial element of our model because it accommodates a wide range of reasons why a firm would choose to export the majority of its output in the absence of subsidies with ESR - e.g. producing a sophisticated good that is not demanded locally, belonging to a global value chain, or having a well-developed network of foreign customers, among others. The magnitude of the distortions produced by a given combination of subsidy and ESR is shaped by the share of firms that are induced to change their allocation of sales between the domestic and foreign market when the policy is in place. This in turn is intimately connected to the natural distribution of export intensity prevailing in the country offering the subsidy.

We study a scenario in which one country unilaterally offers firms located there an ad-valorem subsidy on total sales subject to an ESR. That is, the subsidy is made available only to firms with

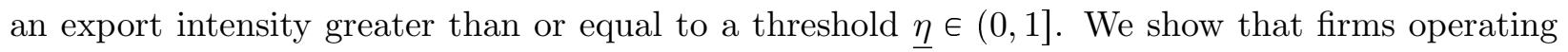
subject to the ESR can be of one of three types: constrained or unconstrained regular exporters and pure exporters. The first two types sell in both markets and differ in terms of whether they would 
have operated at an export intensity at least as high as the ESR threshold under laissez-faire or not. The former - i.e. the unconstrained regular exporters - can operate at their optimal export intensity and still obtain the subsidy. Conversely, a subset of firms that would have operated at an export intensity below $\underline{\eta}$ - the constrained regular exporters - are induced to alter their allocation of sales across markets to receive the subsidy. We show that these firms simultaneously reduce their domestic sales and increase their exports in order to achieve an export intensity exactly equal to the ESR threshold. Furthermore, we show that the reduction in profits caused by a firm not operating at its natural export intensity increases with the difference between the latter and $\underline{\eta}$. Thus, firms with relatively high export intensity but still below the ESR are the ones for which the profit boost provided by the subsidy is likely to exceed the loss associated with the misallocation of sales across markets. Lastly, relatively less productive firms choose to satisfy the ESR and receive the subsidy by becoming pure exporters - thereby saving on the fixed cost of selling domestically. An important result emerging from our model is that the provision of a subsidy with an ESR strictly below $100 \%$ increases the share of exporters operating at the export intensity threshold, but also the share of pure exporters.

The parameters of our model are calibrated to reflect the share of exporters and salient features of the distribution of export intensity in a hypothetical, large developing country that does not provide subsidies subject to ESR, with the intention to capture the distribution of export intensity that would have prevailed in China had it not provided subsidies with ESR. We estimate the natural export intensity distribution by combining information on the use of subsidies with ESR by developing countries gathered from the U.S. State Department's Investment Climate Statements and cross-country firm-level data on firms' export intensity from the World Bank's Enterprise Surveys for the period 2002-2012. We also use the export intensity distribution observed in China in 2013 - a point in which important incentives subject to ESR at the national level had been phased out — as a robustness check of our results.

Undertaking a comprehensive evaluation of all subsidies subject to ESR in China is beyond the scope of our paper for two reasons. Firstly, as we document in detail in Section 2, China imposes ESR on a wide range of incentives, such as tariff concessions, cash transfers and tax breaks. Secondly, there is extremely limited systematic data available on the size and scope of subsidies offered to exporters in China (Lardy, 1992; Claro, 2006; Girma et al., 2009; Haley and 
Haley, 2013). ${ }^{9}$ With these issues in mind, we utilize our quantitative model to investigate the effect of one country unilaterally providing an $8.7 \%$ ad-valorem subsidy on total sales subject to a $70 \%$ ESR. This subsidy provides a profit boost to recipient firms of the same magnitude as a deduction in the corporate income tax rate - from 30 to $10 \%$ — offered to foreign-invested enterprises and Chinese-owned firms located in free trade zones with an export intensity of at least $70 \%$. The latter policy, which was in place between 1991 and 2008, is one of the best documented incentives subject to ESR with the broadest coverage at the national level. Using our model we investigate the effect of the subsidy on firms' mode of operation, aggregate exports, the intensity of competition and welfare, both in the country providing the subsidy and the rest of the world. To put our results in context, we contrast the above scenario with the laissez-faire equilibrium and with a situation in which an equivalent (in terms of the total subsidy expenditure being the same as in the case with ESR) ad-valorem subsidy is provided to all exporters regardless of their export intensity.

Our quantitative exercise reveals that, given our conjectured natural export intensity distribution, introducing a subsidy with ESR with the aforementioned features (which amounts to a total expenditure in subsidies of $0.34 \%$ of GDP in our model) can account for slightly less than half of exporters with an export intensity above 70\% observed in China between 2000 and 2006 . Approximately two thirds of the firms that change their export intensity relative to laissez-faire choose to operate as constrained exporters while the remaining operate as pure exporters. ${ }^{10}$

We find that imposing an export share requirement increases aggregate exports more than the equivalent unconditional subsidy (the exports/GDP ratio increases by $9.3 \%$ with the former compared to $1.4 \%$ with the latter). However, when ESR are imposed, the price index in the enacting country increases, while the opposite happens with the unconditional subsidy. This effect is driven both by constrained regular exporters increasing their domestic prices to reach the export intensity necessary to gain access to the subsidy and by pure exporters not selling their products domestically anymore. The higher profitability of domestic sales under ESR reduces the probability that a firm will choose to exit the market after learning the realization of its productivity and demand shifters.

\footnotetext{
${ }^{9}$ For instance, China did not provide the required subsidy rates or annual amount budgeted for export-related subsidies in either of their notifications to the WTO Committee on Subsidies and Countervailing Measures in 2006 and 2011. The notifications were also silent about the extent of subsidies provided at the provincial and local level. See "Request from the United States to China," October 11, 2011, reference G/SCM/Q2/CHN/42.

${ }^{10}$ In the working paper version of the paper we also experiment with the subsidy being granted on the basis of a firm's export sales alone. Under these circumstances, two thirds of the increase in the share of high-intensity exporters is accounted for by pure exporters (Defever and Riaño, 2016b).
} 
Conversely, when the subsidy is unconditionally granted to all exporters, their expansion drives up the real wage faced by local producers, thereby increasing the intensity of competition.

The combination of export promotion and lower intensity of domestic competition in the enacting country suggest that imposing ESR on subsidies results in what can be described as "protectionism through exporting." That is, the policy increases aggregate exports while simultaneously providing greater protection for relatively low-profitability domestic firms. Such a strategy, however, comes at a substantial cost in terms of efficiency. While both conditional and unconditional subsidies lower welfare in the enacting country, the subsidy with ESR that we investigate reduces real income by $1.37 \%$ in comparison with $0.18 \%$ when no requirements are imposed.

A strong reliance on encouraging exports while at the same time protecting the domestic market has been a key objective of the Chinese Communist Party along China's transition towards a market economy (Rodrik, 2014). This dualist trade policy regime in which a system of exportoriented enclaves coexists with a highly protected domestic economy has been aptly described by Feenstra (1998) as "one country, two systems". Although the rationale motivating the initial implementation of subsidies subject to ESR has long subsided, China's regionally-decentralized governance has enabled their long-lasting permanence. Because of their positive effect on exports and domestic profitability, the use of these subsidies is closely aligned with the objectives of local officials who enjoy a considerable degree of autonomy and for whom career progression is tied to the aforementioned indicators of economic performance (Branstetter and Feenstra, 2002; Xu, 2011). Additionally, because subsidies with ESR hinder the market selection effects of trade liberalization — as we show in this paper — they can be rationalized as an instrument aimed at achieving a 'reform without losers' (Lau et al., 2000).

Related Work. Despite their widespread use, the existing literature on subsidies with ESR is rather sparse, with no quantitative work available. Export share requirements have previously been studied as a second-best policy instrument by Davidson et al. (1985) and Rodrik (1987). We depart from this earlier theoretical literature in two key respects. Firstly, our heterogeneous-firm model allows us to investigate the endogenous choice of firms to operate subject to an export requirement, while both Davidson et al. and Rodrik assume that ESR are exogenously imposed on a subset of firms. Secondly, our quantitative model sheds light on the magnitude of the distortions 
engendered by the imposition of export requirements relative to an equivalent unconditional subsidy which is available to all exporters.

Our paper adds to several strands of literature. It contributes to the growing body of research that quantifies the welfare and productivity effects of China's "unorthodox" trade and investment policies (Bajona and Chu, 2010; Khandelwal et al., 2014; Holmes et al., 2015). Our analysis of subsidies with ESR is also related to the literature studying trade policy in models with heterogeneous firms (Chor, 2009; Demidova and Rodríguez-Clare, 2009; Davies and Eckel, 2010; Felbermayr et al., 2012; Cherkashin et al., 2015; Costinot et al., 2015), as well as to the body of work investigating the welfare implications of free trade zones and trade-related investment measures (TRIMs) (Hamada, 1974; Miyagiwa, 1986; Chao and Yu, 2014).

The rest of the paper is organized as follows. Section 2 provides an overview of fiscal incentives featuring export share requirements in China. Section 3 presents our quantitative general equilibrium model, and Section 4 spells out our strategy to calibrate the model's parameters. Section 5 presents the results of our counterfactual experiments. Section 6 concludes.

\section{Subsidies with Export Share Requirements in China}

In this section we provide a concise overview of policy measures in place in China between 2000 and 2006 that feature incentives conditioned on firms' export intensity exceeding a stated threshold. Section 1 of the online Appendix provides a detailed description of the laws and regulations discussed below.

Subsidies featuring export share requirements were a key innovation introduced as part of the opening-up reforms launched in 1979. Their objective was to facilitate China's interaction with the rest of the world without disrupting its socialist economy. ${ }^{11}$ Despite clearly outgrowing their original purpose, subsidies with ESR have remained ubiquitous in China, even after it joined the WTO in 2001. They target three types of firms primarily: Chinese-owned firms located in Free Trade Zones (FTZ), foreign-invested enterprises (FIE) and establishments devoted to export processing activities (PTE). It is important to clarify that Free Trade Zones and duty drawback

\footnotetext{
${ }^{11}$ This policy objective was explicitly stated in the ideological justification for the establishment of the first special economic zones in Guangdong and Fujian. Borrowing from ideas first proposed by Lenin, it was argued that a communist country could not exist without having ties with the rest of the world. This exchange however, had to operate based on capitalist relations, at least in its early stages (Chan et al., 1986).
} 
schemes such as China's processing trade regime are permitted under WTO agreements. However, if a policy measure is conditioned on export performance either de jure such as in the examples provided below or de facto, it would then infringe on Article 3 of the Agreement on Subsidies and Countervailing Measures (ASCM) as well as the TRIMs agreement. ${ }^{12}$

Figure 2 decomposes the export intensity distribution presented in Figure 1 according to whether exporters belong to one of the three types of firms usually targeted by subsidies subject to ESR. The contrast in the distribution of export intensity between the two groups is, once again, striking. The vast majority of high intensity exporters would be eligible — based on their location, ownership status or trade arrangement - to benefit from subsidies subject to ESR; low-intensity exporters, on the other hand, are more likely to be Chinese-owned firms operating outside an FTZ and not exporting through the processing regime. See Appendix A for further details regarding the procedure we use to identify each group of firms.

Figure 2: Export Intensity Distribution according to Eligibility to Receive Subsidies with ESR

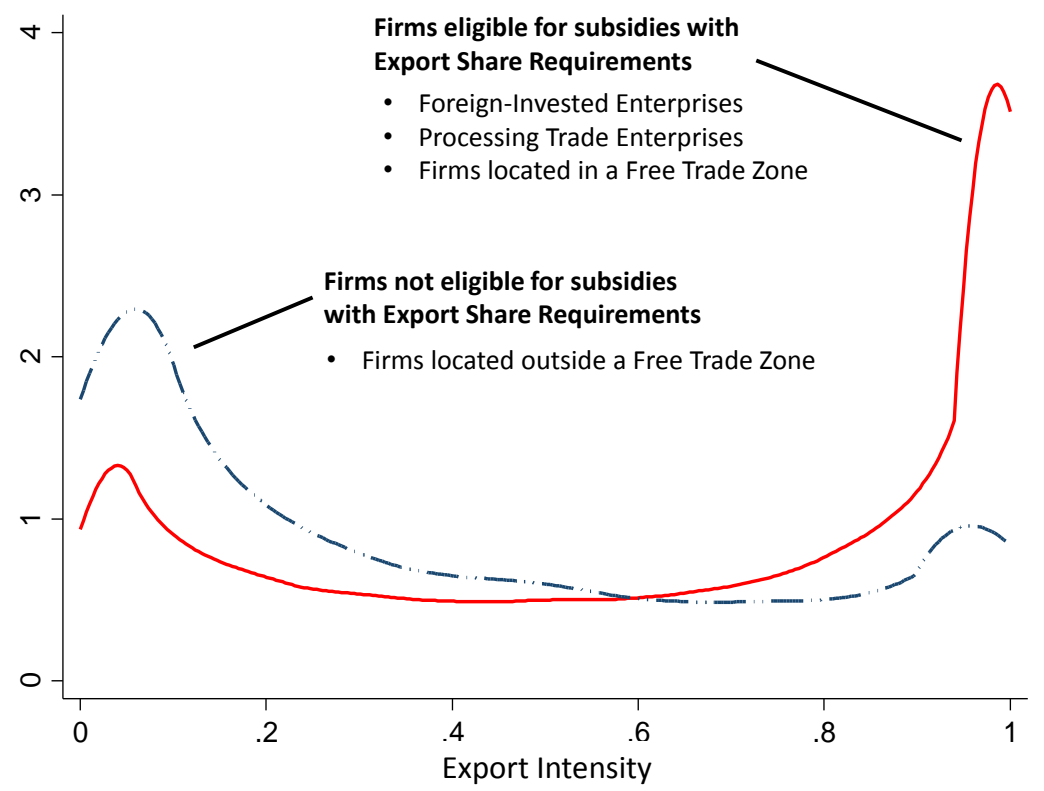

The figure depicts the kernel density of export intensity, defined as the share of exports in total sales, for Chinese manufacturing firms reporting a positive value of exports. Data are for the period 2000-2006 and are described in detail in Appendix A.

\footnotetext{
${ }^{12}$ We thank Petros Mavroidis and Luca Rubini for clarifying this point from a legal perspective.
} 
Free Trade Zones. Free Trade Zones are export-oriented enclaves designed to attract both foreign and domestic investors by providing tax concessions, streamlined regulations, duty-free imports of materials and equipment used for exporting, among other allowances. FTZs in China vary tremendously in terms of the incentives they provide as well as their size, ranging from small enclosed areas to entire prefecture-cities. Appendix A describes the procedure utilized to identify firms operating in these zones; B provides the complete list of prefecture-cities considered.

A crucial objective ascribed to FTZs is to be "laboratories" to test market-oriented policies before their potential implementation in the rest of the economy (Wang, 2013). One of the main components of Deng Xiaoping's package of economic reforms aimed at reintegrating China into the world economy was to designate four counties in Guangdong and Fujian provinces as Special Economic Zones in 1979. The following two decades witnessed the establishment of a large number of FTZs in cities located primarily along the eastern seaboard (see Figure B.1 in Appendix B), where the vast majority of China's export-oriented industrial production is concentrated.

China's corporate income tax regime provides a prime example of the type of incentives available to firms operating in FTZs which are conditioned on ESR. The statutory corporate income tax rate prevailing in China between 1991 and 2008 was 30\%. ${ }^{13}$ Chinese-owned firms, however, could reduce their tax rate to $10 \%$ by locating in an FTZ and exporting more than $70 \%$ of their output. As a result of several complaints at the WTO by the European Union, the U.S. and Canada, China modified its corporate income tax legislation substantially in January 2008. Under the new law, a corporate income tax rate of $25 \%$ applies both to domestic and foreign companies, and any incentives conditioned on ESR have been eliminated. A five-year transition period was established so that the new tax law became fully operational in 2013.

Provincial and local managers of FTZs compete fiercely with each other, particularly in seeking to attract FIEs, and therefore offer a wide array of additional incentives linked to export performance such as tax deductions, access to soft loans and priority access to infrastructure and land. For instance, Standard Chartered Bank (2007) reports that the city of Shenzhen, China's first special economic zone with a total area of $493 \mathrm{~km}^{2}$, offers firms that have paid all their value-added taxes on inputs and that export the entirety of their production, a $5 \%$ sales cash subsidy. The Shenzhen Special Economic Zone also halves the land use fee charged on certified "enterprises-for-

\footnotetext{
${ }^{13}$ Corporate Income Tax Law of the People's Republic of China, 16 September 1991, Article 5.
} 
export." Similarly, most Export Processing Zones specify strict requirements for firms' domestic sales allowance - usually $30 \%$ of the total volume of sales. The first 15 pilots of this new type of zone were set up in 2000, and their number has more than tripled over the last decade. Chinese provincial and local governments seem keen to continue experimenting with new strategies to develop geographically-enclosed areas in which high export intensity firms are encouraged to locate.

Foreign Invested Enterprises. The "Twenty-two regulations," established in 1986 with the objective of attracting foreign investment, defined an "export-oriented" firm as a manufacturing enterprise whose export volume accounts for $50 \%$ or more of its annual sales. ${ }^{14}$ FIEs exceeding this threshold benefitted from preferential land-use policies, easier access to finance and exemptions from industrial and commercial consolidated tax. Until 2001, being an export-oriented firm was a requirement for foreign investments in China and FIEs had to explicitly specify the share of their sales that they intended to sell in China by contract. ${ }^{15}$ Firms that did not comply with this requirement faced steep penalties; for instance, FIEs that did not meet the targets set for exportoriented enterprises within three years from the day they began production, were required to repay $60 \%$ of the tax refunded. ${ }^{16}$ After China joined the WTO, the law on Foreign Capital Enterprises, which was revised in October 2000, lifted the requirement for FIEs to export the majority of their production. Nevertheless, financial incentives conditional on export intensity have remained in place after 2001 .

The first paragraph of the 1991 corporate income tax law stated that "The establishment of enterprises with foreign investment which export all or the greater part of their production should be encouraged." 17 Similarly to Chinese-owned firms located in FTZ, FIEs that export more than $70 \%$ of their output see their corporate income tax rate reduced from 30 to $10 \%$. However, unlike domestically-owned firms, FIEs are not restricted to be located in FTZ to enjoy this incentive. ${ }^{18}$

The 1995 set of regulations entitled "Guiding the Direction of Foreign Investment" also featured restrictions on local sales for FIEs. According to this law, all foreign investment projects were

\footnotetext{
${ }^{14}$ Enforcement of the Provisions of the State Council on Encouraging Foreign Investment, January 1, 1987.

${ }^{15}$ Circular of the Ministry of Foreign Trade and Economic Cooperation on Submission of Import and Export Plans for Enterprises with Foreign Investment, October 25, 2000.

${ }^{16}$ Corporate Income Tax Law of the People's Republic of China, 30 June 1991, Article 8.4.4.

${ }^{17}$ Corporate Income Tax Law of the People's Republic of China', 9 April 1991, Basic Regulations. 8.1.

18، Corporate Income Tax Law of the People's Republic of China', 30 June 1991, Article 8.3.5.
} 
classified in one of four categories: encouraged, permitted, restricted and prohibited. Restricted projects that exported at least $70 \%$ of their total sales were, however, automatically considered as permitted. ${ }^{19}$ This regulation is still in place today, despite China substantially revising the list of restricted products after joining the WTO. The 2002 regulation has introduced a new project category called "all-for export projects." Such projects are treated as encouraged projects automatically and therefore enjoy preferential treatment,${ }^{20}$ such as a $20 \%$ refund of import duties and import value-added tax..$^{21}$

The generous tax concessions available to FIEs have driven local Chinese entrepreneurs to engage in what is known as "round-tripping" — i.e. setting up shell companies in Hong Kong, Macau and Taiwan (HMT), which produce and export goods from Chinese plants, enjoying tax breaks of substantial magnitude (Prasad and Wei, 2007). HMT-based foreign-invested firms account for approximately half of all FIEs and more than half of Processing Trade Enterprises operating in China.

Processing Trade Enterprises. China established the legal framework for processing trade in 1979, thus allowing the duty-free importation of inputs and components needed for the production of goods for export (Naughton, 1996; Fernandes and Tang, 2012). Since the early 1990s, assembling and processing have consistently accounted for approximately half of China's exports. From a legal standpoint, Processing Trade Enterprises (PTEs) are production enterprises or factories established by business enterprises but with independent accounting and their own business licence.

Enterprises engaged in processing are required to obtain a production capability certification as well as a processing trade approval certificate granted by government authorities; they also face strict controls over their domestic sales. These enterprises are allowed to import inputs duty-free as long as they are not used for domestic consumption. In the event that any output is sold in the domestic market, firms must promptly pay the tariffs and VAT on the imported materials. More importantly, they must obtain approval from both the provincial commerce authorities and customs office for an import licence; failing to do so entails a penalty ranging from 30 to $100 \%$ of the declared value of the imported materials and parts. ${ }^{22}$ In practice, firms engaged in export processing either

\footnotetext{
${ }^{19}$ Regulations for Guiding the Direction of Foreign Investment, June 7, 1995, Article 11.

${ }^{20}$ Regulations for Guiding the Direction of Foreign Investment, February 11, 2002.

${ }^{21}$ General Administration of Customs and State Administration of Taxation, 4 September 2002.

${ }^{22}$ Hong Kong Trade Development Council (2003), Guide to Doing Business in China, Chapter on Processing-Trade. Based on the circular concerning issuance of "Interim Measures on Administration of the Examination and Approval
} 
become fully export-oriented or are forced to set up separate facilities to sell domestically in order to reduce the leakage of tariff-free intermediate goods (Hong Kong Trade Development Council, 2009; Brandt and Morrow, 2013).

In order to enjoy greater autonomy to sell domestically, a processing trade enterprise has to change its registration and become a FIE, which requires it to temporarily stop its production for a customs auditing. The consulting company Li \& Fung Group (2012) estimates that this production disruption takes approximately 9 to 12 months. Furthermore, the transformation from PTE to FIE involves the work of more than 10 government departments and can potentially result in a substantial tax repayment.

PTEs can also import equipment provided by a foreign client to be used in processing duty-free. To obtain this benefit, the PTE has to be an independent factory devoted to export processing, which in turn requires it to export all its production. If the PTE does not count with a processingoriented facility, it needs to specify in the terms of their processing trade contract that at least $70 \%$ of its output must be exported.

\section{Model}

Preferences. Consider a world consisting of two countries, Home $(H)$ and Foreign $(F)$. Each country $i \in\{H, F\}$, is inhabited by $L_{i}$ identical consumers who supply one unit of labor inelastically. The representative consumer in each country has Dixit-Stiglitz preferences with elasticity of substitution $\sigma>1$. Utility in country $i$ is given by:

$$
\mathcal{U}_{i}=\left[\sum_{j}\left(\int_{\omega \in \Omega_{j i}}\left[z_{j i}(\omega)^{\frac{1}{\sigma-1}} q_{j i}(\omega)\right]^{\frac{\sigma-1}{\sigma}} d \omega\right)\right]^{\frac{\sigma}{\sigma-1}}, i, j \in\{H, F\}
$$

where $\Omega_{j i}$ is the set of varieties produced in country $j$ which are available to consumers in country $i, q_{j i}(\omega)$ is the quantity of good $\omega$ consumed and $z_{j i}(\omega)$ is a demand shifter for variety $\omega$, with a higher value of $z(\omega)$ corresponding to higher demand for good $\omega$. As Eaton et al. (2011) show, firm-destination heterogeneity in demand is necessary to reconcile the observed variation in firms'

of Processing Trade" and "Interim Measures on Administration of the Examination and Approval of Domestic Sale of Bonded Materials and Parts Imported for Processing Trade", Ministry of Foreign Trade and Economic Cooperation (1999, WJMGF. No. 314 and No. 315). 
exports relative to domestic sales with the Melitz (2003) model. Similarly, Munch and Nguyen (2014) find that firm-destination effects explain half of the variation in export sales across narrowly defined product-destination markets using Danish data. In addition to the direct interpretation of $z(\omega)$ as representing cross-country variation in consumers' taste for a specific variety, Crozet et al. (2012) argue that these demand shifters can also stand in for the extent of a firm's network of connections with purchasers in each market.

The utility function (1) yields the following iso-elastic demand function in country $i$ for variety $\omega$ produced in $j$ :

$$
q_{j i}(\omega)=A_{j i}(\omega) p_{j i}(\omega)^{-\sigma}, \text { with } A_{j i}(\omega) \equiv E_{i} P_{i}^{\sigma-1} z_{j i}(\omega)
$$

where $E_{i}$ and $P_{i}$ denote, respectively, the aggregate expenditure and price index in country $i$. The latter is given by:

$$
P_{i}=\left[\sum_{j}\left(\int_{\omega \in \Omega_{j i}} z_{j i}(\omega) p_{j i}(\omega)^{1-\sigma} d \omega\right)\right]^{\frac{1}{1-\sigma}}, \quad i, j \in\{H, F\}
$$

Production. Firms in country $i$ incur an initial investment $f_{i}^{e}$ to learn their idiosyncratic productivity, $\varphi$, and demand shifters $\left(z_{i i}, z_{i j}\right) .{ }^{23}$ We assume that the domestic and export demand shifters are drawn from the same cumulative distribution, $F_{z}$, with support $(0, \infty)$, and are independent from each other. Productivity is drawn from a distribution $F_{\varphi}$, and is assumed to be independent of demand shifters. With a slight abuse of notation, let $\omega \equiv\left(\varphi, z_{i i}, z_{i j}\right)$ denote a firm's state vector. Based on their knowledge of $\omega$, firms first choose whether to stay in or exit the market. If a firm decides to operate, it produces using a linear technology with labor as the sole input, $q=\varphi l$. Thus, the marginal cost for a firm with productivity $\varphi$ located in country $i$ is $w_{i} / \varphi$, where $w_{i}$ is the wage prevailing in that country.

We assume that firms face a strictly positive location-specific fixed cost to sell their output in each country, following Eaton et al. (2011). Thus, for instance, a Home-based firm pays $w_{H} f_{H H}$ when selling domestically and $w_{H} f_{H F}$ when it exports to Foreign. ${ }^{24}$ Moreover, exporters from

\footnotetext{
${ }^{23}$ All fixed costs in the model are denominated in units of labor.

${ }^{24}$ Notice that our assumption of location-specific fixed costs implies that these incorporate both production and market access costs.
} 
country $i$ selling in market $j$ incur a transport $\operatorname{cost} \tau_{i j} \geqslant 1$ on their export sales, while no transport costs are involved in selling domestically, i.e. $\tau_{i i}=1$.

Laissez-Faire. As is well known, conditionally on selling in the domestic market, a firm based in country $i$ charges an optimal price that exhibits a constant mark-up above its marginal cost, $p_{i i}(\omega)=\frac{\sigma}{\sigma-1} \frac{w_{i}}{\varphi} ;$ similarly, a firm charges the same price augmented by the transport cost $\tau_{i j}$ when it exports its output, i.e. $p_{i j}(\omega)=\frac{\sigma}{\sigma-1} \frac{\tau_{i j} w_{i}}{\varphi}$. Due to the existence of fixed costs, not all operating firms choose to sell both domestically and to export. Thus, in the absence of subsidies, we can identify three types of firms in the model according to the markets they sell to: firms that sell only domestically (indexed by $d$ ), pure exporters, i.e. producers that export all their output (indexed by $x$ ), and regular exporters, which sell their output both at home and abroad (indexed by $d x$ ). Letting $k \in\{d, x, d x\}$ indicate a firm's mode of operation, profits for firm $\omega$ of type $k$ located in country $i$, are given by:

$$
\pi_{i}^{k}(\omega)=\sum_{j}\left[\kappa \tau_{i j}^{1-\sigma} A_{i j}(\omega)\left(\frac{\varphi}{w_{i}}\right)^{\sigma-1}-w_{i} f_{i j}\right] \cdot 1_{i j}^{k}(\omega), \quad i, j \in\{H, F\}
$$

where $\kappa \equiv(\sigma-1)^{\sigma-1} \sigma^{-\sigma}$ and $1_{i j}^{k}(\omega)$ is the indicator function taking the value 1 when firm $\omega$ of type $k$ located in country $i$ sells some of its output in market $j$, and zero otherwise.

Since the marginal cost of production is constant, a firm based in country $i$ finds profitable to export to country $j$ if the gross profit accrued from selling to that market exceeds the fixed cost $w_{i} f_{i j}$. This implies that for a given level of productivity $\bar{\varphi}>0$, a firm $\omega$ located in country $i$ chooses to sell in country $j$ if its demand shifter in that market, $z_{i j}$, exceeds the cutoff value $z_{i j}^{*}(\bar{\varphi})=\frac{w_{i}^{\sigma} \tau_{i j}^{\sigma-1} f_{i j}}{\kappa E_{j} P_{j}^{\sigma-1} \bar{\varphi}^{\sigma-1}}>0$. Moreover, since demand shifters have support $(0, \infty)$, are independent from each other, and fixed costs are strictly positive, it follows that the three types of firms coexist in equilibrium for any given, strictly positive, level of productivity. ${ }^{25}$ Any firm that draws demand shifters below $z_{i i}^{*}$ and $z_{i j}^{*}$ does not produce at all. Firms that draw a high demand shifter for their product abroad while simultaneously experiencing low domestic demand choose to be pure

\footnotetext{
${ }^{25}$ Without the firm-destination-specific demand shifters, not only all regular exporters would earn the same share of their revenue abroad, but pure exporters could not coexist alongside domestic firms and regular exporters in equilibrium. In the context of a two-country model in which firms differ only in their productivity, regular exporters coexist only with domestic firms if $f_{i i} / f_{i j} \leqslant \tau_{i j}^{\sigma-1}\left(E_{i} / E_{j}\right)\left(P_{i} / P_{j}\right)^{\sigma-1}$. If the converse holds, then only regular and pure exporters arise in equilibrium.
} 
exporters, while firms in the opposite situation choose instead to sell only domestically. Lastly, firms for which product appeal in each market exceeds the respective cutoff sell in Home and Foreign. ${ }^{26}$ It also follows from the definition of the demand shifter cutoffs above, that they are decreasing in productivity. This means that, everything else equal, highly productive firms are more likely to operate as regular exporters selling their output both domestically and abroad.

Conditional on selling in both markets, the export intensity of a firm is given by:

$$
\eta_{i}^{*}(\omega)=\frac{\tau_{i j}^{1-\sigma} A_{i j}(\omega)}{A_{i i}(\omega)+\tau_{i j}^{1-\sigma} A_{i j}(\omega)} .
$$

While $\eta_{i}^{*}(\omega)$ varies across exporters due to differences in firm-destination-specific demand shifters, it is independent of productivity because the elasticity of demand and markups in each market are constant. However, due to the existence of fixed costs, productivity matters for the decision of whether to sell in both markets or to operate as a pure exporter. Thus, we define an exporter's "natural" export intensity, $\eta_{i}^{k}(\omega)$, as the share of its total sales accounted for by exports, when no subsidies are available:

$$
\eta_{i}^{k}(\omega)= \begin{cases}\eta_{H}^{*}(\omega) & \text { if } k=d x \\ 1 & \text { if } k=x\end{cases}
$$

The fact that our model delivers a non-degenerate distribution of firms' natural export intensity is critical for our objective of assessing the consequences of subsidies with ESR. Firms choose to export the majority of their output for a wide range of reasons besides the availability of incentives contingent on export performance. For instance, they may produce goods for which there is little domestic demand (what Díaz de Astarloa et al. (2013) call "orphan industries", e.g. woolen sweater producers in Bangladesh), or operate as links in a global value chain, assembling components into a new product that is exported to the next stage of production. Such naturally-occurring highintensity exporters certainly benefit from the availability of subsidies with ESR, but as will become clear below, do not need to distort their behavior to receive these incentives. Firms that would have chosen to rely more on domestic sales under laissez-faire, might, on the other hand, find profitable to distort their allocation of sales across markets to comply with the ESR and enjoy the incentives

\footnotetext{
${ }^{26}$ More precisely, the shares of regular exporters, pure exporters and domestic firms, for a given productivity level $\bar{\varphi}$ are given by, $\left[1-F_{z}\left(z_{i i}^{*}\right)\right]\left[1-F_{z}\left(z_{i j}^{*}\right)\right], F_{z}\left(z_{i i}^{*}\right)\left[1-F_{z}\left(z_{i j}^{*}\right)\right]$, and $\left[1-F_{z}\left(z_{i i}^{*}\right)\right] F_{z}\left(z_{i j}^{*}\right)$ respectively.
} 
associated with it.

Subsidies with Export Share Requirements. We now introduce a subsidy subject to an export share requirement (ESR) at Home. Exporters with an export intensity of at least $\underline{\eta} \in(0,1]$, receive an ad-valorem subsidy $s_{r}$ on their total sales. ${ }^{27}$

When the subsidy with ESR is available, a Home firm maximizes profits by choosing among three possible alternatives:

$$
\pi_{H}(\omega)=\max \left\{\pi_{H}^{d}(\omega), \pi_{H}^{-\mathrm{ESR}}(\omega), \pi_{H}^{E S R}(\omega)\right\}
$$

namely, it can operate domestically, export some of its output without being subject to the ESR (indexed by -ESR, in which case the firm operates at an export intensity strictly below $\underline{\eta}$ ), or it can comply with the export share requirement, thus receiving the aforementioned subsidy, $s_{r}$. Notice that the maximum profit for domestic firms and regular exporters not satisfying the ESR is still given by (4) in the scenario without subsidies, with $\pi_{H}^{-\mathrm{ESR}}(\omega)=\pi_{H}^{d x}(\omega)$.

The profit maximization problem of a Home firm subject to the ESR constraint and receiving an ad-valorem subsidy $s_{r}$ on its sales reads:

$$
\begin{aligned}
\pi_{H}^{\mathrm{ESR}}(\omega)=\max _{\left\{q_{H j}(\omega) \geqslant 0\right\}} & \sum_{j \in\{H, F\}}\left\{\left[\left(1+s_{r}\right) A_{H j}^{\frac{1}{\sigma}}(\omega)\left(q_{H j}(\omega)\right)^{-\frac{1}{\sigma}}-\left(\frac{w_{H} \tau_{H j}}{\varphi}\right)\right] q_{H j}(\omega)-w_{H} f_{H j}\right\} \cdot 1_{H j}(\omega) \\
\text { subject to: } & \frac{A_{H F}^{\frac{1}{\sigma}}(\omega)\left(q_{H F}(\omega)\right)^{\frac{\sigma-1}{\sigma}}}{A_{H H}^{\frac{1}{\sigma}}(\omega)\left(q_{H H}(\omega)\right)^{\frac{\sigma-1}{\sigma}}+A_{H F}^{\frac{1}{\sigma}}(\omega)\left(q_{H F}(\omega)\right)^{\frac{\sigma-1}{\sigma}}} \geqslant \underline{\eta}
\end{aligned}
$$

where $1_{H j}(\omega)$ is the indicator function taking the value 1 if Home firm $\omega$ operating under the ESR constraint sells a positive quantity in market $j$. The solution to problem (8) is summarized in the following proposition:

Proposition 1 The profit maximization problem of a firm receiving an ad-valorem sales subsidy $s_{r}$ subject to an export share requirement $\underline{\eta} \in(0,1)$ is characterized by three potential solutions,

\footnotetext{
${ }^{27}$ In the working paper version of the paper (Defever and Riaño, 2016b), we also consider subsidies to fixed costs and an ad-valorem subsidy based on export sales. The main conclusions of our analysis remain unchanged.
} 
depending on the export intensity that a firm would choose if it sold its output both domestically and abroad, $\eta_{H}^{*}(\omega)$, and its productivity, $\varphi$.

1. Constrained regular exporter $(k=d x c)$ : A firm for which $\eta_{H}^{*}(\omega)<\underline{\eta}$ and with productivity exceeding the cutoff value $\varphi^{d x c}\left(\omega ; \underline{\eta}, s_{r}\right)$ chooses to satisfy the export share requirement with an export intensity exactly equal to the ESR threshold $\underline{\eta}$. The firm realizes profits,

$$
\pi_{H}^{d x c}(\omega)=\kappa\left(1+s_{r}\right)^{\sigma} \Theta(\omega, \underline{\eta})\left(\varphi / w_{H}\right)^{\sigma-1}-\left(f_{H H}+f_{H F}\right) w_{H} .
$$

The firm-specific profit shifter term $\Theta(\omega, \underline{\eta})$ is given by:

$$
\Theta(\omega, \underline{\eta})=\frac{A_{H H}(\omega) A_{H F}(\omega)}{\left[(1-\underline{\eta})^{\frac{\sigma}{\sigma-1}} A_{H F}(\omega)^{\frac{1}{\sigma-1}}+\underline{\eta}^{\frac{\sigma}{\sigma-1}} \tau_{H F} A_{H H}(\omega)^{\frac{1}{\sigma-1}}\right]^{\sigma-1}},
$$

and the productivity cutoff, $\varphi^{d x c}\left(\omega ; \underline{\eta}, s_{r}\right)$, such that $\pi_{H}^{d x c}(\omega)=\pi_{H}^{x}(\omega)$, is:

$$
\varphi^{d x c}\left(\omega ; \underline{\eta}, s_{r}\right)=\left[\frac{w_{H}^{\sigma} f_{H H}}{\kappa\left(1+s_{r}\right)^{\sigma}\left(\Theta(\omega, \underline{\eta})-\tau_{H F}^{1-\sigma} A_{H F}(\omega)\right)}\right]^{\frac{1}{\sigma-1}} .
$$

2. Unconstrained regular exporter $(k=d x u)$ : A firm for which $\eta_{H}^{*}(\omega) \geqslant \underline{\eta}$ and with productivity exceeding the cutoff value $\varphi^{d x u}\left(\omega ; s_{r}\right)$, sells both domestically and abroad and operates at its natural export intensity. In so doing, it accrues profits,

$$
\pi_{H}^{d x u}(\omega)=\kappa\left(1+s_{r}\right)^{\sigma}\left(A_{H H}(\omega)+\tau_{H F}^{1-\sigma} A_{H F}(\omega)\right)\left(\varphi / w_{H}\right)^{\sigma-1}-\left(f_{H H}+f_{H F}\right) w_{H}
$$

The productivity cutoff $\varphi^{d x u}\left(\omega ; s_{r}\right)$, such that $\pi_{H}^{d x u}(\omega)=\pi_{H}^{x}(\omega)$, is given by:

$$
\varphi^{d x u}\left(\omega ; s_{r}\right)=\left[\frac{w_{H}^{\sigma} f_{H H}}{\kappa\left(1+s_{r}\right)^{\sigma} A_{H H}(\omega)}\right]^{\frac{1}{\sigma-1}}
$$

3. Pure exporter $(k=x)$ : A firm for which,

(i) $\eta_{H}^{*}(\omega)<\underline{\eta}$ and $\varphi<\varphi^{d x c}\left(\omega ; \underline{\eta}, s_{r}\right)$, or,

(ii) $\eta_{H}^{*}(\omega) \geqslant \underline{\eta}$ and $\varphi<\varphi^{d x u}\left(\omega ; s_{r}\right)$ 
operates as a pure exporter and realizes profits:

$$
\pi_{H}^{x}(\omega)=\kappa\left(1+s_{r}\right)^{\sigma} \tau_{H F}^{1-\sigma} A_{H F}(\omega)\left(\varphi / w_{H}\right)^{\sigma-1}-f_{H F} w_{H}
$$

When $\underline{\eta}=1$, the only admissible solution for a firm wishing to receive the subsidy $s_{r}$ is to operate as a pure exporter.

Proof. See Appendix C.

Corollary 1 A constrained regular exporter receiving subsidies with ESR sets a higher price domestically and a lower price in the foreign market than if the ESR were not binding.

\section{Proof. See Appendix C.}

In order to provide the intuition regarding the different cases that characterize the solution to problem (8), let us first consider the case in which a firm sells its output both domestically and abroad. For a given vector of demand shifters, a firm $\omega$ chooses to export a unique share $\eta_{H}^{*}(\omega)$ of its sales, since operating at any other export intensity would lower its profits. If $\eta_{H}^{*}(\omega) \geqslant \underline{\eta}$, then the firm does not need to change its optimal export intensity to satisfy the export requirement and receive the subsidy $s_{r}$. An unconstrained regular exporter lowers its domestic and export prices in proportion to the subsidy $s_{r}$ relative to laissez-faire - in the same way as it would if it had received an unconditional sales subsidy — and realizes profits (12).

A firm that in the absence of subsidies would have chosen an export intensity below $\underline{\eta}$, on the other hand, needs to change the quantities it sells in each market in order to exactly reach an export intensity $\underline{\eta}$ and achieve profits (9). ${ }^{28}$ It follows then, that a firm would only choose to operate as a constrained regular exporter if the subsidy it receives more than compensates for the foregone profit associated with distorting its sales mix across the domestic and foreign markets. Corollary 1 reveals that constrained regular exporters increase their export intensity by simultaneously curtailing domestic sales and increasing exports, which is achieved by increasing the price they charge domestically and lowering the price of their exports.

\footnotetext{
${ }^{28}$ The profit-shifting term $\Theta(\omega, \underline{\eta})$ in (9) is a strictly concave function of $\underline{\eta}$, reaching a global maximum at $\eta_{H}^{*}(\omega)$, with $\Theta\left(\omega, \eta_{H}^{*}\right)=A_{H H}(\omega)+\tau_{H F}^{1-\sigma} A_{H F}(\omega)$. Thus, it follows that conditional on selling domestically and abroad, a firm for which $\eta_{H}^{*}(\omega)<\underline{\eta}$ would not choose an export intensity greater than $\underline{\eta}$ to satisfy the ESR constraint.
} 
Figure 3: Firm Types Operating at Home when Subsidies with ESR are Offered There

(i) Domestic

$$
\text { Exporters }\left\{\begin{array}{l}
(i i) \text { Not subject to ESR } \\
\text { Satisfying ESR }\left\{\begin{array}{l}
(i i i) \text { Constrained regular exporters } \\
(i v) \text { Unconstrained regular exporters } \\
(v) \text { Pure exporters }
\end{array}\right.
\end{array}\right.
$$

A firm can also satisfy the ESR by becoming a pure exporter. This is the case when a firm's productivity is not sufficiently high to operate as a regular exporter. The relevant productivity cutoff depends on whether a firm would operate as a constrained or unconstrained regular exporter if it were to sell in both markets - i.e. (11) or (13). When a subsidy with ESR is available, pure exporters realize profits (14).

To sum up, there are five types of firms operating at Home when this country offers a subsidy subject to ESR, represented in Figure 3. Having established a taxonomy of the type of firms that operate in the country providing subsidies subject to ESR, we show in Appendix D that given the rich degree of heterogeneity incorporated in our model, all five types of firms coexist - taking as given the level of aggregate variables - for any given level of productivity $\bar{\varphi}$. Moreover, we also show that for a given subsidy rate $s_{r}$ there exists a level of export intensity $\widehat{\eta}\left(s_{r}\right) \in(0, \eta]$ such that regular exporters with an export intensity greater than $\widehat{\eta}\left(s_{r}\right)$ but below $\underline{\eta}$ choose to operate as constrained regular exporters once the subsidy subject to ESR becomes available. As the subsidy becomes more generous, regular exporters with lower export intensity become more likely to adjust their sales to comply with the ESR.

General Equilibrium. We now describe the conditions that characterize the general equilibrium in our model. As noted above, we assume that only Home offers subsidies with ESR. We assume that the Home government runs a balanced budget and finances the export subsidy with a lump-sum tax levied on households. 
Choosing labor at Home as the numeraire $\left(w_{H}=1\right)$, and given a subsidy rate $s_{r}$ subject to an ESR threshold $\underline{\eta} \in(0,1]$, equilibrium in the model is characterized by a vector of seven endogenous variables,

$$
\left\{M_{H}, M_{F}, P_{H}, P_{F}, E_{H}, E_{F}, w_{F}\right\}
$$

all of which have been defined above, with the exception of $M_{H}$ and $M_{F}$, which denote the mass of operating firms at Home and Foreign respectively. Equilibrium is such that in each country,

(i) the labor market clears,

(ii) expected profits of entering the market exactly cover entry costs,

(iii) Total expenditure in country $i$ is given by: $E_{i}=w_{i} L_{i}-T_{i}$, where $T_{i}$ is the aggregate tax revenue used to finance export subsidies,

and,

(iv) international trade is balanced.

Appendix E describes the algorithm used to solve the model numerically, and spells out in detail the market-clearing equations listed above.

\section{Calibration}

This section describes the procedure used to assign values to the endowments, preferences and technology parameters of our model economy. We calibrate our model so as to reproduce salient features of the distribution of export intensity of a hypothetical, large developing country that does not provide subsidies subject to ESR.

Natural Export Intensity Distribution. We utilize cross-country firm-level data drawn from the World Bank's Enterprise Surveys (WBES) for the years 2002-2012 to construct a natural export intensity distribution that is not distorted by subsidies with ESR and that will serve as the laissezfaire benchmark in our quantitative exercise. Our sample consists of manufacturing exporters located in the twenty largest developing and transition countries in terms of population (i.e. those 
with at least 30 million inhabitants), for which there are at least 100 exporters available in WBES. We choose to restrict our sample to firms in relatively large countries because our objective is to infer the counterfactual distribution that would have prevailed in China in the absence of subsidies with ESR; moreover, Defever and Riaño (2015b) show that the share of high-intensity exporters observed in a country is crucially influenced by its size relative to the rest of the world.

We collect information on whether a country provides or not subsidies with ESR from the Investment Climate Statements produced by the U.S. State Department. ${ }^{29}$ Table 1 presents the countries included in our sample, as well as the number of exporters and the share of high-intensity exporters (i.e. those with export intensity above 70\%) operating in each country. The last three columns of the table indicate whether subsidies with ESR are also conditioned on a firm's location or ownership status. The column "Everywhere" indicates that any firm can benefit from subsidies with ESR regardless of their location; "within a FTZ" indicates that the subsides are only available to firms located in a Free Trade Zone, and the last column "FIE" indicates that only ForeignInvested Enterprises are eligible. Since countries often implement several policy measures subject to ESR at the same time, these categories are not mutually exclusive.

Table 1 reveals the high prevalence of ESR across developing countries - twelve out of the twenty countries in our sample offer incentives to firms conditioned on fulfilling an explicit export share requirement. Figure 4 presents the weighted distribution of export intensity for exporters based on the availability of subsidies with ESR. Similarly to what we have documented in the case of China, the difference between the two distributions is remarkable - on average half of exporters in countries offering subsidies with ESR export $70 \%$ or more of their output, while only $12 \%$ do so in countries that do not offer these incentives (the distribution for the latter group of firms closely resembles the one for domestically-owned Chinese firms located outside FTZ presented in Figure 2). This marked contrast provides further suggestive evidence regarding the role of subsidies with ESR in distorting the distribution of export intensity. ${ }^{30}$

\footnotetext{
${ }^{29}$ The Investment Climate Statements are publicly available for the years 2005 to 2012 at http://2001-2009. state.gov/e/eeb/ifd/2005/ and http://www.state.gov/e/eb/rls/othr/ics/. The information on the availability of subsidies with ESR is found in the sections on "Performance Requirements and Incentives" and "Foreign Trade Zones/Free Trade Zones".

${ }^{30}$ The WBES data allow us to identify firms with a high proportion of imported intermediate inputs - i.e. firms that are more likely to belong to a global value chain. In our sample of countries not providing subsidies with ESR, $9.24 \%$ of exporters import $90 \%$ or more of their intermediate inputs. These firms have a substantially higher export intensity than firms that are less reliant on imported inputs and partially explain the small hump at the upper bound of the export intensity distribution in Figure 4. In the context of our model, these firms would have drawn
} 
Figure 4: Export Intensity Distribution According to Availability of Subsidies with ESR in Large Developing Countries

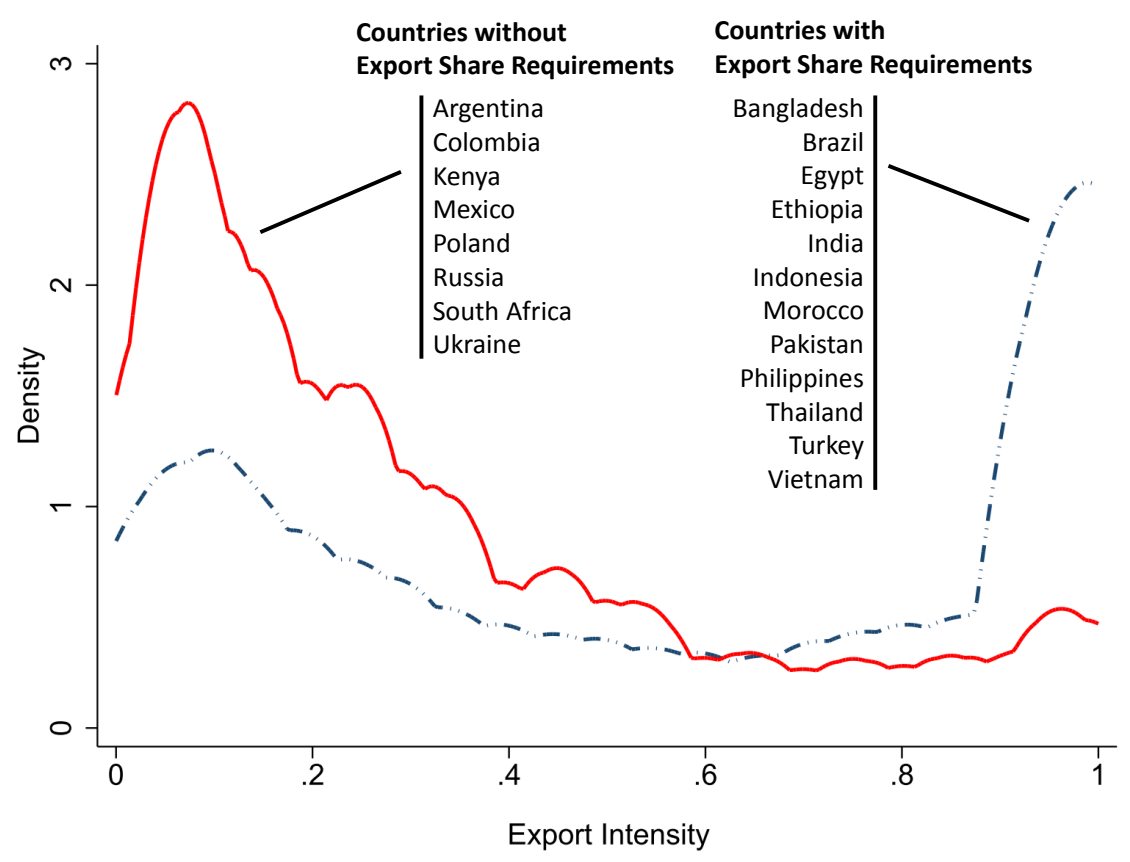

The figure depicts the kernel density of export intensity, which is defined as the share of exports in total sales for firms reporting a positive value of exports. Data are from the World Bank's Enterprise Surveys (WBES) for the period 2002-2012.

We use the export intensity distribution for exporters located in non-ESR countries - the solid line in Figure 4 - as the natural export intensity distribution when calibrating our model. It is important to note that when computing both the densities in Figure 4 and the moments targeted in the calibration, each firm-level export intensity observation is weighted so that each country receives an equal weight. This ensures that the distributions are not driven by outliers, or sample size and population differences across countries.

Assigned Parameters. In order to calibrate our model, we assume that both Home and Foreign countries are identical in terms of their labour endowments and model parameters. Thus, firms in both countries draw productivity and destination-specific demand shifters from the same distributions. This assumption also implies that the fixed costs of entry and operation in each market are such that $f_{i}^{e}=f_{j}^{e}=f^{e}, f_{i i}=f_{j j}=f^{d}$ and $f_{i j}=f_{j i}=f^{x}$ for $i, j \in\{H, F\}$ and $i \neq j$. Since scaling up or down all fixed costs by the same amount does not affect the aggregate variables of interest simultaneously high foreign and low domestic demand shifters. 


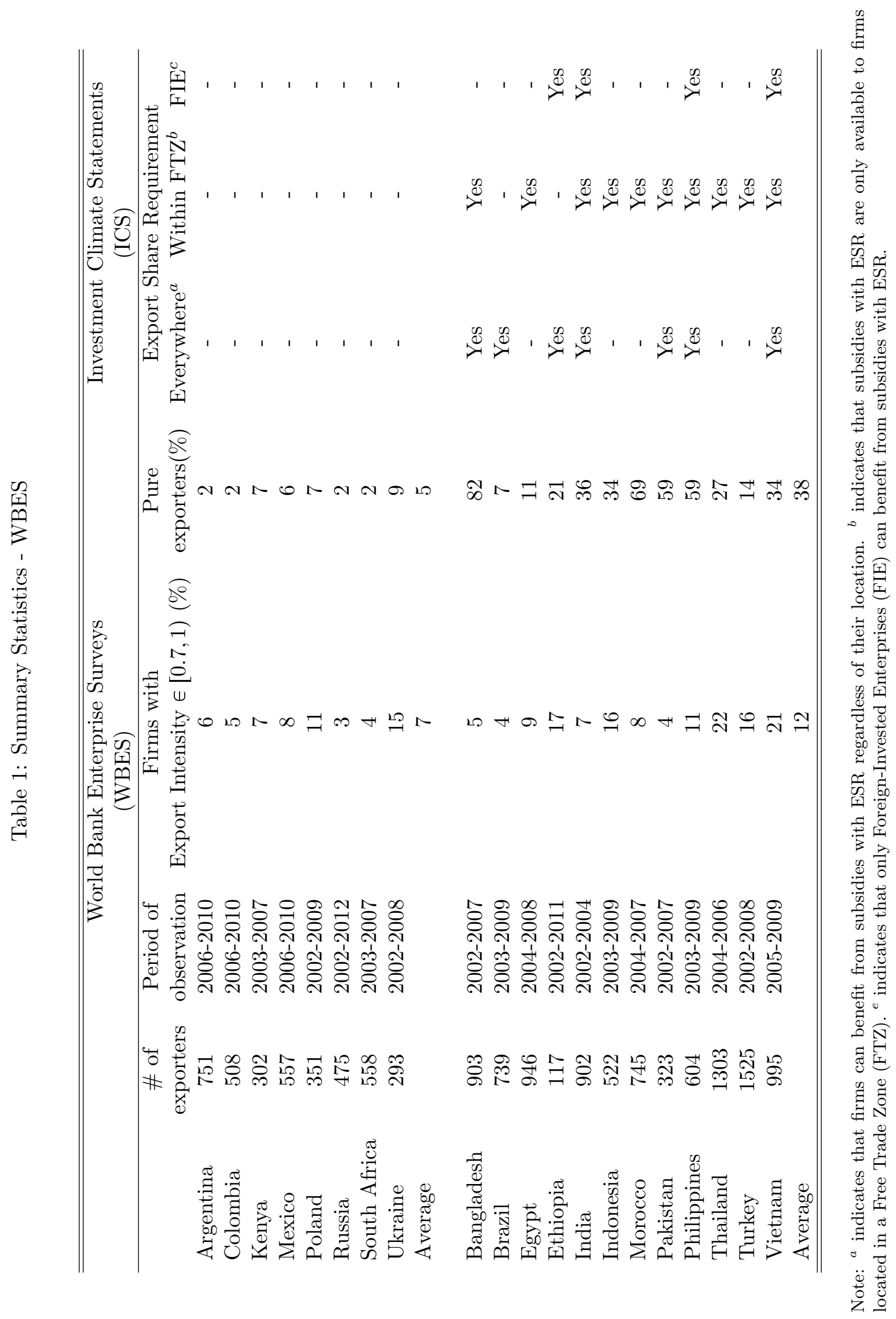


— just as in Melitz and Redding (2015) — we normalize the domestic fixed cost $f^{d}$ to 1.

We assume that both Home and Foreign have the same population, and therefore set $L=1$. Taking Home (i.e. the country enacting subsidies with ESR) to represent China, then Foreign in our model corresponds to a country with the combined population of the U.S., Canada and the European Union (Khandelwal et al., 2014).

We set the elasticity of substitution, $\sigma$, equal to 3, based on Broda and Weinstein (2006). ${ }^{31}$ Firms in both countries draw their productivity realizations from a Pareto distribution with lower bound 1 and shape parameter $a$. Following Helpman et al. (2004), we estimate $a-(\sigma-1)$ by regressing the logarithm of a firm's employment ranking on the logarithm of its employment level using data from our sample of countries not offering subsidies with ESR. The estimated coefficient of 0.713 implies a value of $a=3.213$, given our choice of $\sigma$.

Similarly to other model parameters, the iceberg transport cost incurred is assumed to be the same for both countries, i.e. $\tau_{H F}=\tau_{F H}=\tau$. In models that do not feature firm-destinationspecific demand shifters (e.g. Melitz and Redding, 2015), transport costs are usually calibrated to match a country's mean export intensity. ${ }^{32}$ In our model, however, changes in transport costs or in the mean of demand shifters both affect the export intensity distribution. The only difference between transport costs and the mean of export demand shifters, is that the former affects the price of exports relative to the domestic market price while the latter does not. Since we do not have information on prices that allows us to separately identify the two parameters, we set $\tau$ equal to 1.7 following Anderson and van Wincoop (2004).

Calibrated Parameters. There are 5 parameters that remain to be calibrated, which we choose so as to minimize the distance between a number of moments in the model and in the data. These are the sunk cost of entry, $f^{e}$, the fixed cost of exporting, $f^{x}$, and the parameters governing the distribution of firm-specific domestic and export demand shifters. We assume that the latter are both drawn from independent lognormal distributions with parameters $\left(\mu_{d}, \sigma_{d}^{2}\right)$ and $\left(\mu_{x}, \sigma_{x}^{2}\right)$, which

\footnotetext{
${ }^{31}$ We have also experimented with an elasticity of substitution of 3.5 , which is the average value of the median import demand elasticities at the SITC 3-digit level for Argentina, Colombia, Mexico and Poland, the four countries belonging to our undistorted benchmark for which Broda et al. (2006) have estimates available, and which is in turn very close to China's estimate of 3.42 , and our results remain robust. Table G.1 presents further robustness checks in which we perturb our calibrated parameters one at a time.

${ }^{32}$ Recall that in the Melitz (2003) model with two identical countries, all exporters have the same export intensity, $\tau^{1-\sigma} /\left(1+\tau^{1-\sigma}\right)$.
} 
denote the mean and variance of the underlying normal distribution for each demand shifter. We set $\mu_{d}=-0.5 \sigma_{d}^{2}$ so that domestic demand shifters have a mean of 1 . The moments we target are the share of exporting firms $(37.42 \%)$ and the 10th, 50th, 75th and 90th percentiles of the distribution of export intensity in countries that do not provide subsidies with ESR.

Table 2: Parameter Values

\begin{tabular}{lc}
\hline \hline Description & Value \\
\hline \hline Assigned parameters: & \\
Country size $(L)$ & 1 \\
Elasticity of substitution $(\sigma)$ & 3 \\
Shape parameter productivity distribution $(a)$ & 2.713 \\
Scale parameter productivity distribution $(\underline{\varphi})$ & 1 \\
Fixed cost — domestic sales $\left(f^{d}\right)$ & 1 \\
Transport cost $(\tau)$ & 1.7 \\
& \\
Calibrated parameters: & \\
Fixed cost — entry $\left(f^{e}\right)$ & 10.342 \\
Fixed cost - exporting $\left(f^{x}\right)$ & 0.637 \\
Domestic demand shifters $\left(\ln \left(z_{i i}\right) \sim \mathcal{N}\left(\mu_{d}, \sigma_{d}^{2}\right)\right)$ & $(-0.634,1.267)$ \\
Export demand shifters $\left(\ln \left(z_{i j}\right) \sim \mathcal{N}\left(\mu_{x}, \sigma_{x}^{2}\right)\right)$ & $(-1.807,0.507)$ \\
\hline \hline
\end{tabular}

Figure 5: Model Fit — Export Intensity Distribution in Countries without Subsidies with ESR

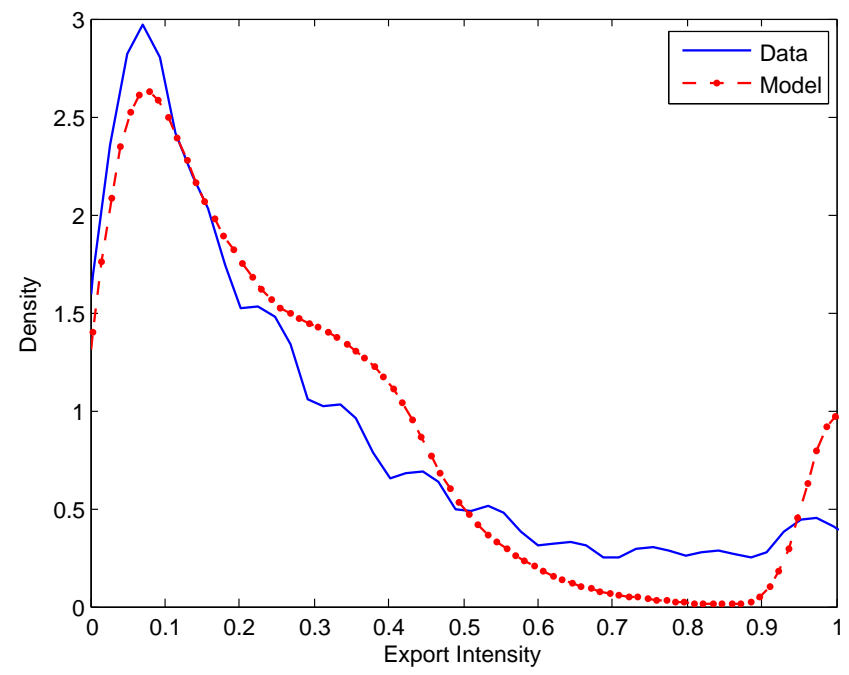

The figure depicts the probability density function of export intensity (conditional on exporting) after simulating the model 1,000 times and compares it with the empirical density calculated for the sample of countries that do not provide subsidies with ESR. 
Table 2 summarizes the parameters used to solve the model. Our model fits the distribution of export intensity quite well, as Figure 5 shows, although we overstate the share of pure exporters, which is not a targeted moment. The model implies an employment size premium for exporters vis-à-vis domestic firms of 1.17 log points (relative to 1.31 in our sample of non-ESR countries), which is very close to the estimates by Bernard et al. (2007) and Mayer and Ottaviano (2007) for U.S. and European firms (1.19 and 1.21) respectively.

\section{The Effect of Subsidies with Export Share Requirements}

We now investigate the effect of utilizing subsidies with export share requirements on firms' mode of operation, the distribution of export intensity, the intensity of competition and welfare in our model economy.

Policy Experiment. As we have documented in Section 2, there are several policy measures that provide incentives to firms subject to ESR in China. Besides differences in the underlying policy measure, e.g. tax holidays, duty-free access to intermediate inputs and capital goods, finance at below-market rates and subsidized utilities, these incentives also differ in terms of their specific ESR thresholds (in some cases these can even be firm-specific), additional location and/or ownership requirements and administrative scope (e.g. incentives might be provided at the national, provincial or prefecture-city level). Thus, carrying out a comprehensive quantitative evaluation of the effect of subsidies with ESR in China is beyond the scope of this paper.

We instead choose to pursue a more modest objective. We utilize the corporate income tax rate deduction from $30 \%$ to $10 \%$ provided to foreign-invested firms and domestically-owned producers located in FTZ that exported 70\% or more of their output over the period 1991-2008 to pin down the ESR threshold and subsidy rate that we employ for the quantitative analysis. This policy measure is appealing both because it was set at the national level and had a broad coverage (Figure B.1

in Appendix B shows that the FTZ location requirement for locally-owned firms is not unduly restrictive). Moreover, since this tax break was fully phased out in 2013, it allows us to use data from the 2013 wave of WBES for China to re-calibrate the parameters governing the natural export intensity distribution to provide a robustness check of our results. 
From the model standpoint, a corporate income tax deduction is equivalent to an ad-valorem subsidy, in that they both increase a firm's gross-profit. More formally, consider a statutory tax rate $\bar{t}$ and a reduced corporate tax rate $\underline{t}<\bar{t}$. Assuming that fixed costs are fully deducted from the corporate income tax base and given the iso-elastic demand defined in equation (2), it follows that a corporate income tax deduction leads to an optimal profit that takes the form:

$$
\pi_{H}(\omega)=\left(\frac{1-\underline{t}}{1-\bar{t}}\right) \mathcal{B}_{H}(\omega, \bar{t})-w_{H} \mathcal{F}
$$

where $\mathcal{B}_{H}(\omega, \bar{t})=(1-\bar{t}) \kappa \mathcal{A}_{H}(\omega)\left(\varphi / w_{H}\right)^{\sigma-1}$ denotes the after-tax gross profit taxed at the statutory tax rate $\bar{t}, \mathcal{A}_{\mathcal{H}}(\omega)$ is a stand-in for the relevant demand shifter applying to Home firm $\omega,{ }^{33}$ and $\mathcal{F}$ is the relevant fixed cost that a firm incurs determined by the markets it serves. The term $\left(\frac{1-\underline{t}}{1-\bar{t}}\right)$ corresponds to the gross-profit increase generated by the corporate tax deduction from $\bar{t}$ to $\underline{t}$. Thus, the deduction in the corporate income tax rate from $30 \%$ to $10 \%$ enjoyed by firms satisfying a $70 \%$ ESR increases their gross profits by $28.6 \%(=0.9 / 0.7)$ relative to firms that do not comply with the export requirement.

Similarly, as can be seen from the profit function of firms operating subject to ESR (see equations (9), (12) and (14)), the sales subsidy that we consider in our model boosts firms' gross profits by a factor $\left(1+s_{r}\right)^{\sigma}$. Therefore, given our choice of $\sigma=3$, we can calculate the ad-valorem subsidy $s_{r}$ that provides a gross profit shift equivalent to that offered by the tax rate deduction described above:

$$
(1+s)^{\sigma}=\frac{1-\underline{t}}{1-\bar{t}} \Rightarrow s_{r}=\left(\frac{1-\underline{t}}{1-\bar{t}}\right)^{\frac{1}{\sigma}}-1=\left(\frac{0.9}{0.7}\right)^{\frac{1}{3}}-1 \approx 0.087
$$

Thus, in our benchmark experiment, we assume that Home's government offers an $8.7 \%$ ad-valorem subsidy to total sales for firms with an export intensity of at least $70 \%$.

Benchmark Results. We first investigate how the availability of a subsidy subject to ESR affects the mode of operation choice for firms at Home. Under laissez-faire $10.5 \%$ of exporters, the majority of which are pure exporters, have a natural export intensity above $70 \%$. Following the introduction of the subsidy with ESR, the share of exporters with an export intensity above

\footnotetext{
${ }^{33} \mathcal{A}_{\mathcal{H}}(\omega)$ will be equal to $A_{H H}(\omega)+\tau_{H F}^{1-\sigma} A_{H F}(\omega)$ for a regular exporter, $\Theta(\omega, \eta)$ for a constrained regular exporter, and $\tau_{H F}^{1-\sigma} A_{H F}(\omega)$ for pure exporters. See Bauer et al. (2014) for an example where the corporate income tax is levied on net profits (including fixed costs).
} 
the ESR threshold increases to $23 \%$. To put this figure in context, the subsidy we consider in our experiment could account for $46 \%$ of the exporters with an export intensity of $70 \%$ or above observed in China between 2000 and 2006, given our hypothesized natural distribution of export intensity. Two thirds of the firms that choose to operate subject to the ESR when the subsidy is available, do so as constrained regular exporters, while the remaining become pure exporters (their share among exporters increases by 7.8 and 4.8 percentage points respectively). ${ }^{34}$ It is important to note that our quantitative exercise is likely to overestimate the mass point in the distribution of export intensity at $70 \%$, since we do not consider the potential administrative burden that firms subject to the ESR face when selling domestically. Firms enjoying the tax reduction may need to demonstrate that they effectively sold less than $30 \%$ of their output on the domestic market. This could entail paying a customs inspector to verify the valuation of shipments sold domestically, or even to use different production establishments or separated production lines for their exports. Pure exporters, on the other hand, are less likely to bear these costs.

Given the subsidy rate and ESR combination used in our policy experiment, we find that the value for $\widehat{\eta}\left(s_{r}\right)$, the export intensity at which a firm is indifferent between operating as a constrained regular exporter or not satisfying the ESR, is $44.7 \%$. This is $60 \%$ higher than the overall mean export intensity under laissez-faire. We find that constrained regular exporters are $10 \%$ more productive than the average Home exporter when there is no subsidy in place, while firms that become pure exporters are $32 \%$ less productive than the same reference group. Thus, we can see that the selection pattern induced by the ESR constraint is heterogeneous with respect to firms' productivity. On the one hand, firms that operate at the ESR threshold are sufficiently productive to incur the fixed costs involved in selling at home and abroad. On the other hand, relatively less productive firms prefer instead to become pure exporters, since by doing so they benefit from the subsidy with ESR and economize on the fixed cost required to sell domestically.

Table 3 presents the impact of sales subsidies, both unconditional and with ESR, vis-à-vis laissez faire on several equilibrium variables such as exports/GDP, price indices, the unconditional probability of firm exit and welfare. In this exercise, we contrast the $8.7 \%$ subsidy on total sales granted to firms with an export intensity of at least $70 \%$, with a $0.43 \%$ ad-valorem sales subsidy

\footnotetext{
${ }^{34}$ When the subsidy with ESR is granted only on export sales, the opposite pattern emerges — two thirds of firms that decide to operate facing the ESR given the same subsidy rate choose to operate as pure exporters; see Defever and Riaño (2016b).
} 
made available to all exporters regardless of their export intensity. Both policies result in Home's aggregate expenditure on export subsidies being $0.34 \%$ of GDP.

We first note that the subsidy subject to ESR shares several key features with an unconditional sales subsidy granted to all exporters. Both instruments increase aggregate exports in the enacting country, reduce welfare and produce qualitatively similar effects on Home's trade partner. More precisely, the provision of subsidies to Home exporters lowers the price of a subset of Home's export varieties, intensifying import competition in Foreign and lowering the price index there. Restoring trade balance, in turn, requires Foreign's wage to fall so that firms located there become more competitive, and ultimately, increase their exports to Home. The fall in the price index in Foreign more than compensates the reduction in its nominal wage, and thus welfare (i.e. real income) in Foreign increases at the expense of Home. ${ }^{35}$

Unlike an unconditional subsidy, however, Table 3 shows that a subsidy subject to ESR increases the price index in the enacting country. Recall from Corollary 1 that constrained regular exporters raise domestic prices in order to satisfy the $70 \%$ export share threshold. On average, these exporters set a $27.3 \%$ higher markup on domestic prices relative to what they would have charged in the absence of subsidies. Additionally, as more firms also choose to become pure exporters, the varieties they produce stop being available to local consumers altogether, driving up the price index (the cost of achieving one unit of utility) at Home. All in all, the price index in the country providing the subsidy increases by $0.49 \%$ relative to laissez-faire. Conversely, when the unconditional sales subsidy for exporters is in place, the lower price of imports from Foreign as well as the stronger selection effect induced by the subsidy granted to exporters, puts downward pressure on Home's price index. The higher profitability of selling domestically experienced by Home firms when there is a subsidy subject to ESR also results in these firms becoming more likely to remain in operation after they realize their productivity and demand shifters compared to the laissez-faire and unconditional subsidy scenarios. More precisely, when subsidies are conditioned on firms' export intensity, the ex-ante probability of a firm choosing not operate falls by $5 \%$ relative to the situation without

\footnotetext{
${ }^{35}$ Similarly, Felbermayr et al. (2012) show that Home's welfare falls when it offers an unconditional ad-valorem subsidy on export sales, while Foreign's wage falls and welfare increases. In the context a small economy model (in which Home's actions do not affect Foreign outcomes by definition), Demidova and Rodríguez-Clare (2009) also find that an unconditional export subsidy lowers Home's terms-of-trade and welfare. The same qualitative implications obtain when the subsidy subject to ESR is granted on the basis of export sales alone.
} 
Table 3: Comparison of Subsidies with respect to Laissez-Faire

\begin{tabular}{|c|c|c|}
\hline Variable & $\begin{array}{c}\text { Subsidy with Export } \\
\text { Share Requirements } \\
\text { (1) }\end{array}$ & $\begin{array}{l}\text { Unconditional Sales } \\
\text { Subsidy for Exporters } \\
(2)\end{array}$ \\
\hline & \multicolumn{2}{|c|}{$\%$ change w.r.t. laissez-faire } \\
\hline Wage, Foreign & -3.736 & -0.878 \\
\hline Price index, Home & 0.492 & -0.157 \\
\hline Price index, Foreign & -4.187 & -0.952 \\
\hline Probability of exit, Home & -4.982 & 2.015 \\
\hline Probability of exit, Foreign & -2.163 & -0.353 \\
\hline Welfare, Home & -1.375 & -0.181 \\
\hline Welfare, Foreign & 0.470 & 0.075 \\
\hline \multirow[t]{2}{*}{ Exports/GDP } & 9.319 & 1.441 \\
\hline & \multicolumn{2}{|c|}{ percentage point change w.r.t. laissez-faire } \\
\hline \multicolumn{3}{|l|}{$\begin{array}{l}\text { Share of Home's exporters } \\
\text { with export intensity }\end{array}$} \\
\hline$\in[0.7,1)$ & 7.878 & -0.052 \\
\hline$=1$ & 4.819 & -1.613 \\
\hline \multicolumn{3}{|c|}{$\begin{array}{l}\text { Column (1) compares an } 8.7 \% \text { ad-valorem subsidy to total sales granted to firms with an } \\
\text { export intensity of at least } 70 \% \text { with the laissez-faire equilibrium. Column }(2) \text { compares a } \\
0.43 \% \text { ad-valorem subsidy to total sales made available to all exporting firms regardless of their } \\
\text { export intensity with the laissez-faire equilibrium. Both subsidy schemes result in aggregate } \\
\text { subsidy expenditure accounting for } 0.34 \% \text { of Home's GDP. Neither Home nor Foreign conducts } \\
\text { any trade policy under laissez-faire, but trade costs in both directions are maintained at their } \\
\text { calibrated level (1.7) across all scenarios. }\end{array}$} \\
\hline
\end{tabular}

subsidies, whereas when the sales subsidy is available to all exporters, this probability is $2 \%$ higher than under laissez-faire.

We find that export share requirements exert a quantitatively large effect on several aggregate outcomes. The subsidy subject to ESR boosts exports (as a share of GDP) by $9.3 \%$, while the unconditional subsidy only increases them by $1.44 \%$. Crucially, the additional distortion on the allocation of sales across markets induced by the ESR produces a substantially larger welfare loss for the enacting country compared to that of an unconditional subsidy. Real income at Home falls by $1.37 \%$ with ESR, while the equivalent sales subsidy granted to all exporters results in a $0.18 \%$ welfare loss. The foreign country, on the other hand, always benefits from the availability of cheaper imported goods from Home, faring better when export requirements are imposed; nevertheless, Foreign's welfare gain is always lower than Home's loss. 
Using an Alternative Natural Export Intensity Benchmark. One concern regarding our calibration strategy is that the undistorted distribution of export intensity is based on countries that are too different from China across several dimensions, such as income per capita, openness to trade and attractiveness as a location to set up multinational affiliates. ${ }^{36}$ Since the corporate income tax deduction conditioned on a $70 \%$ ESR in China was terminated in 2008, and fully phased out by 2013, we explore the robustness of our results by using the export intensity distribution observed in China in 2013 as an undistorted scenario. In so doing, we recalibrate our model parameters using the same target moments as in our benchmark exercise discussed above. ${ }^{37}$ It is important to keep in mind, however, that other policy measures featuring export requirements are likely to still be in place in 2013, and these can bias upwards the natural export intensity distribution calibrated on the basis of Chinese data.

Figure 6 presents the distribution of export intensity for Chinese manufacturing firms sampled by the WBES in 2002 and 2013. Critically for our purposes, the distribution in 2002 is quite similar to the one we calculate using the more representative survey carried out by the Chinese National Bureau of Statistics (NBS) and presented in Figure 1. More precisely, the shares of regular exporters with an export intensity of at least $70 \%$ and pure exporters in the 2002 wave of WBES are $23 \%$ and $17.3 \%$ respectively, while in the NBS survey these are $24.9 \%$ and $24.5 \%$. The similitude displayed by the NBS and WBES surveys in 2002 is reassuring when interpreting the distribution based on the latter wave of the WBES survey as a suitable proxy for the distribution of export intensity prevailing in China in 2013. Figure 6 reveals that high-intensity exporters are considerably less prevalent in 2013 than in the 2000-2006 period, with firms with an export intensity above $70 \%$ accounting for only $20.2 \%$ of exporters in 2013 . The share of exporters in China in 2013 - the other moment used to calibrate our model — is $32.6 \%$, a similar figure to that observed between 2000 and $2006(27.90 \%)$, and in the sample of countries not offering subsidies with ESR (37.42\%).

Table F.1 in Appendix F presents the parameters calibrated under this alternative scenario, and Table F.2 reports the results of our comparison. From a qualitative standpoint, the findings

\footnotetext{
${ }^{36}$ As Antràs and Yeaple (2014) note, multinational firms' affiliates tend to be larger, more productive, and crucially, more export-oriented than non-multinational firms.

${ }^{37}$ In Defever and Riaño (2015a), we have also used the distribution of export intensity observed in China in 2013 to illustrate the effect of a subsidy granted solely to pure exporters in a simplified version of our model without firm-destination-specific demand shifters.
} 
Figure 6: Export Intensity Distribution in China in 2002 and 2013 (WBES data)

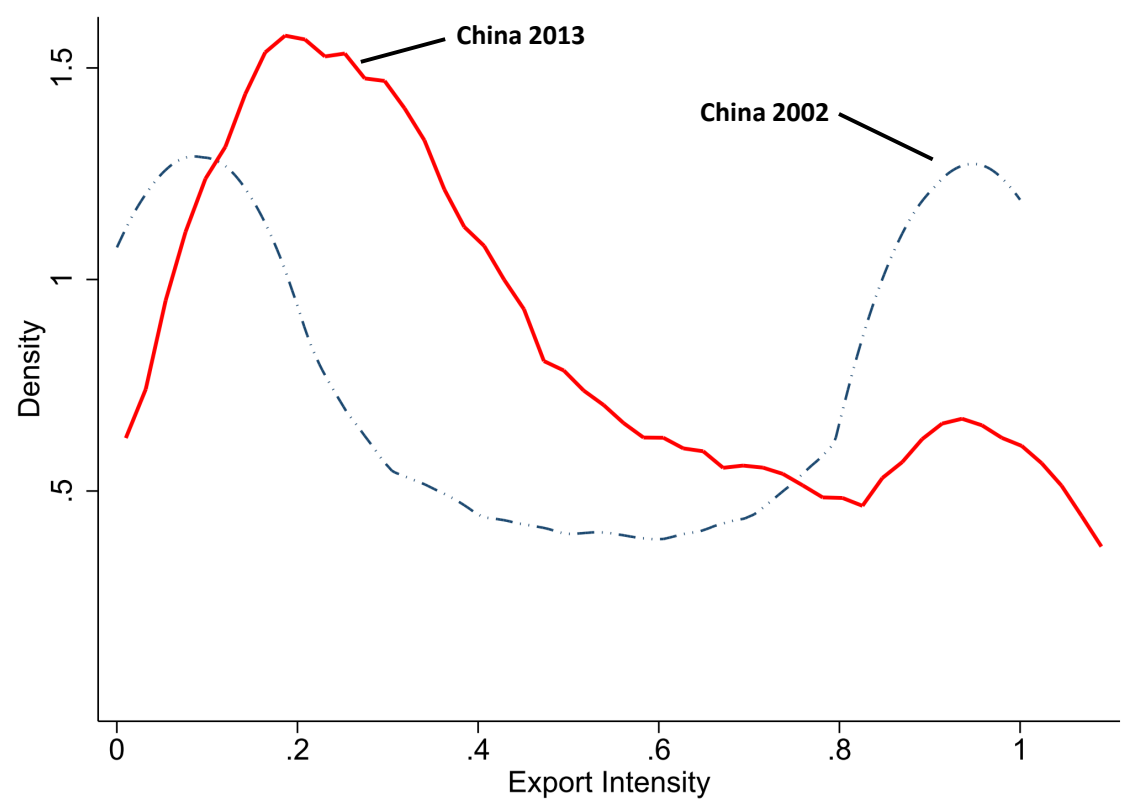

The figure depicts the kernel density of export intensity - the share of exports in total sales - for Chinese manufacturing firms reporting a positive value of exports. Data are drawn from the World Bank's Enterprise Survey carried out in China in 2000 and 2013.

obtained under our benchmark specification remain unaltered. Quantitatively, the aggregate expenditure on subsidies increases substantially — from 0.34 to $1.09 \%$ of GDP — when Home offers an $8.7 \%$ subsidy on total sales subject to a $70 \%$ ESR. This happens both because there are more exporters that are naturally eligible to receive subsidies, but also due to a larger number of firms choosing to become regular constrained exporters. Under this parametrization the overall effect of subsidies on the strength of domestic competition, exports and welfare is considerably larger than in our benchmark.

Further Robustness Analysis. We investigate further the robustness of our results by perturbing individual model parameters in our benchmark scenario to ensure that our conclusions are not unduly driven by our chosen parametrization. To this end, we increase one parameter of interest at a time by $10 \%$ relative to its value in the benchmark calibration and report the comparison between the equilibrium with the subsidy conditioned on ESR and laissez-faire. As the results reported Table G.1 in Appendix G show, our quantitative results are remarkably robust to significant changes in 
the parametrization of the model. ${ }^{38}$

\section{Conclusions}

China's successful insertion into the global economy has spurred great interest in the economic policies that made this feat possible. In this paper we have documented the widespread use of subsidies subject to export share requirements implemented after the opening-up reforms of the late 1970s, several of which are still in place after China joined the WTO in 2001 - a practice that has been deemed highly controversial by other member countries. We use a two-country model of trade with firm heterogeneity in productivity and product appeal across markets to study how the use of this type of subsidy affects individual firms' pricing and production decisions as well as its implications for aggregate outcomes such as total exports, the level of competition and welfare.

Our model shows that imposing ESR on a sales subsidy distorts the distribution of export intensity — the share of a firm's total sales accounted for by exports — in the country offering the incentive. A subset of firms that would have operated at an export intensity below the ESR threshold under laissez-faire, simultaneously increase their domestic prices and lower their export prices in order to satisfy the export intensity constraint with equality. A second group of relatively low-productivity firms choose instead to stop selling in the domestic market altogether to comply with the ESR and receive the corresponding subsidy.

In order to investigate the general equilibrium consequences of using a subsidy with ESR, we carry out a quantitative exercise in which a country unilaterally offers an $8.7 \%$ ad-valorem subsidy on total sales subject to a $70 \%$ ESR. This policy experiment seeks to mimic a well-documented corporate income tax rate deduction from $30 \%$ to $10 \%$ offered to foreign-owned firms and domestic producers located in free trade zones that exported $70 \%$ or more of their sales over the period 1991-2008 in China. In order to provide a benchmark against which to gauge the quantitative effect of utilizing a subsidy with ESR, we compare this policy to laissez-faire and to an equivalent unconditional sales subsidy made available to all exporters regardless of their export intensity.

We parametrize our model so as to reproduce the counterfactual distribution of export intensity

\footnotetext{
${ }^{38}$ We also experiment with allowing the demand shifters to be positively correlated across markets. We find that as demands become more correlated across markets, fewer firms are induced to alter their export intensity in order to satisfy the ESR constraint, and therefore the subsidy subject to ESR becomes less distortive relative to an unconditional one. These results are available upon request.
} 
that would have prevailed in China had subsidies subject to ESR not being employed there. In our benchmark scenario, this object corresponds to the weighted distribution of export intensity among manufacturing exporters observed in 8 large developing countries that do not offer incentives subject to ESR. We also use data for China in 2013 - a period in which our policy of interest had been fully phased out — as a robustness check for our analysis.

Our results show that a sales subsidy of the magnitude described above subject to a $70 \%$ ESR can account for almost half of the share of exporters in China exhibiting an export intensity above the ESR threshold. We find that the subsidy with ESR increases aggregate exports more than the equivalent unconditional sales subsidy granted to all exporters. Crucially, the subsidy subject to ESR increases the profitability of selling domestically in the enacting country, thereby providing greater protection for low-profitability firms, while the unconditional subsidy, on the other hand, increases the ex-ante probability of firms exiting the market. Thus, we characterize the imposition of an export requirement on the sales subsidy as resulting in "protectionism through exporting". Our quantitative exercise shows that the distortion in the allocation of sales between the domestic and export market produced by the imposition of an ESR greatly increase the welfare loss associated with subsidizing exporters.

Our findings also open up exciting avenues for future research. It would be interesting, for instance, to understand better the objectives that have motivated China and so many other developing countries to impose export requirements on subsidies and other incentive measures. One conjecture that follows naturally from our model, is that subsidies with ESR could provide a politically-feasible alternative to full unilateral trade liberalization by eliciting the support of domestic producers that might be harmed by greater trade openness. Another interesting line of inquiry has to do with the dynamic consequences of subsidies subject to ESR. Our current analysis has shown that they produce substantial static welfare losses; however, it is possible that if these subsidies help in fostering industrialization in a country enacting them, the dynamic gains they engender could more than compensate for the distortions that we have identified in this paper.

\section{References}

Anderson, J. E. And E. van Wincoop (2004): "Trade Costs," Journal of Economic Literature, $42,691-751$. 
Antràs, P. And S. R. Yeaple (2014): "Multinational Firms and the Structure of International Trade," in Handbook of International Economics, ed. by G. Gopinath, E. Helpman, and K. Rogoff, Elsevier, vol. 4, 55 - 130 .

Arkolakis, C. (2010): "Market Penetration Costs and the New Consumers Margin in International Trade," Journal of Political Economy, 118, 1151 - 1199.

Bajona, C. And T. Chu (2010): "Reforming State Owned Enterprises in China: Effects of WTO Accession," Review of Economic Dynamics, 13, 800-823.

Bauer, C., R. B. Davies, And A. Haufler (2014): "Economic Integration and the Optimal Corporate Tax Structure with Heterogeneous Firms," Journal of Public Economics, 110, 42-56.

Bernard, A. B., E. J. Blanchard, I. Van Beveren, and H. Y. Vandenbussche (2012): "Carry-Along Trade," NBER Working Paper 18246, National Bureau of Economic Research.

Bernard, A. B., J. Eaton, J. B. Jensen, and S. Kortum (2003): "Plants and Productivity in International Trade," American Economic Review, 93, 1268-1290.

Bernard, A. B., J. B. Jensen, S. J. Redding, and P. K. Schott (2007): "Firms in International Trade," Journal of Economic Perspectives, 21, 105-130.

Bernard, A. B., S. J. Redding, And P. K. Schott (2011): "Multiproduct Firms and Trade Liberalization," The Quarterly Journal of Economics, 126, 1271-1318.

Brandt, L. And P. M. Morrow (2013): "Tariffs and the Organization of Trade in China," Manuscript, University of Toronto.

Brandt, L., J. van Biesebroeck, and Y. Zhang (2012): "Creative Accounting or Creative Destruction? Firm-level Productivity Growth in Chinese Manufacturing ?" Journal of Development Economics, 97, 339-351.

(2014): "Challenges of Working with the Chinese NBS Firm-Level Data," China Economic Review, 30, 339-352.

Branstetter, L. G. And R. C. Feenstra (2002): "Trade and Foreign Direct Investment in China: a Political Economy Approach," Journal of International Economics, 58, 335-358.

Branstetter, L. G. And N. R. Lardy (2008): "China's Embrace of Globalization," in China's Great Economic Transformation, ed. by L. Brandt and T. G. Rawski, Cambridge: Cambridge University Press.

Broda, C., J. Greenfield, And D. Weinstein (2006): "From Groundnuts to Globalization: A Structural Estimate of Trade and Growth," NBER Working Papers 12512, National Bureau of Economic Research.

Broda, C. And D. E. Weinstein (2006): "Globalization and the Gains from Variety," The Quarterly Journal of Economics, 121, 541-585.

Chan, T., E. K. Y. Chen, And S. Chin (1986): "China's Special Economic Zones: Ideology, Policy and Practice," in China's Special Economic Zones: Policies, Problems and Prospects, ed. by Y. C. Jao and C. K. Leung, Oxford: Oxford University Press. 
ChaO, C.-C. And E. S. H. Yu (2014): Trade-Related Investment Measures: Theory and Applications, London: Imperial College Press.

Cherkashin, I., S. Demidova, H. L. Kee, and K. Krishna (2015): "Firm Heterogeneity and Costly Trade: A New Estimation Strategy and Policy Experiments," Journal of International Economics, 96, 18-36.

Chor, D. (2009): "Subsidies for FDI: Implications From a Model with Heterogeneous Firms," Journal of International Economics, 78, 113-125.

Claro, S. (2006): "Supporting Inefficient Firms with Capital Subsidies: China and Germany in the 1990s," Journal of Comparative Economics, 34, 377-401.

Costinot, A., A. Rodríguez-Clare, and I. Werning (2015): "Micro to Macro: Optimal Trade Policy with Firm Heterogeneity," Manuscript, MIT.

Creskoff, S. and P. Walkenhorst (2009): "Implications of WTO Disciplines for Special Economic Zones in Developing Countries," World Bank Policy Research Working Paper 4892.

Crozet, M., K. Head, and T. Mayer (2012): "Quality Sorting and Trade: Firm-level Evidence for French Wine," Review of Economic Studies, 79, 609-644.

Dai, M., M. Maitra, And M. Yu (2016): "Unexceptional Exporter Performance in China? The Role of Processing Trade," Journal of Development Economics, 121, 177-189.

Davidson, C., S. J. Matusz, And M. E. Kreinin (1985): "Analysis of Performance Standards for Direct Foreign Investments," Canadian Journal of Economics, 18, 876-90.

Davies, R. B. And C. Eckel (2010): "Tax Competition for Heterogeneous Firms with Endogenous Entry," American Economic Journal: Economic Policy, 2, 77-102.

Defever, F. And A. Riaño (2015a): "Gone for Good? Subsidies with Export Share Requirements in China: 2002-2013," World Bank Economic Review Papers 63 Proceedings, 29, S125-S144.

(2015b): "Twin Peaks," Manuscript, University of Nottingham.

(2016a): "China's Dual Export Sector," Manuscript, University of Nottingham.

(2016b): "Protectionism through Exporting: Subsidies with Export Share Requirements in China," GEP Working Paper 2016/03, University of Nottingham.

Demidova, S. And A. Rodríguez-Clare (2009): "Trade Policy Under Firm-level Heterogeneity in a Small Economy," Journal of International Economics, 78, 100-112.

Díaz de Astarloa, B., J. Eaton, K. Krishna, B. Y. Aw-Roberts, A. Rodríguez-Clare, AND J. TyBout (2013): "Born-to-Export Firms: Understanding Export Growth in Bangladesh," International Growth Centre Working Paper.

Eaton, J., S. Kortum, And F. Kramarz (2011): "An Anatomy of International Trade: Evidence From French Firms," Econometrica, 79, 1453-1498.

Feenstra, R. C. (1998): "One Country, Two Systems: Implications of WTO Entry for China," Manuscript, University of California, Davis. 
Feenstra, R. C. AND S.-J. Wei (2010): "Introduction to "China's Growing Role in World Trade"," in China's Growing Role in World Trade, National Bureau of Economic Research, $1-31$.

Felbermayr, G., B. Jung, And M. Larch (2012): "Optimal Tariffs, Retaliation and the Welfare Loss from Tariff Wars in the Melitz Model," Journal of International Economics, 89, 13-25.

Fernandes, A. P. And H. TAng (2012): "Determinants of Vertical Integration in Export Processing: Theory and Evidence from China," Journal of Development Economics, 99, 396-414.

Girma, S., Y. Gong, H. Görg, And Z. Yu (2009): "Can Production Subsidies Explain China's Export Performance? Evidence from Firm-level Data," Scandinavian Journal of Economics, 111, 863-891.

Haley, U. C. V. And G. T. Haley (2013): Subsidies to Chinese Industry: State Capitalism, Business Strategy and Trade Policy, Oxford: Oxford University Press.

HamadA, K. (1974): "An Economic Analysis of the Duty Free Zone," Journal of International Economics, 4, 225-241.

Hanson, G. H. (2012): "The Rise of Middle Kingdoms: Emerging Economies in Global Trade," Journal of Economic Perspectives, 26, 41-64.

Helpman, E., M. J. Melitz, and S. R. Yeaple (2004): "Export Versus FDI with Heterogeneous Firms," American Economic Review, 94, 300-316.

Holmes, T. J., E. R. McGrattan, and E. C. Prescott (2015): "Quid Pro Quo: Technology Capital Transfers for Market Access in China," Review of Economic Studies, 82, 1154-1193.

Hong Kong Trade Development Council (2003): Guide to Doing Business in China, HKTDC Business Edition, available at www.hktdc.com.

- (2009): Turning from Export Processing to Domestic Sales, HKTDC Business Edition, available at www.hktdc.com.

Khandelwal, A. K., P. K. Schott, And S.-J. Wei (2014): "Trade Liberalization and Embedded Institutional Reform: Evidence from Chinese Exporters," American Economic Review, 103, 2169-2195.

LARDy, N. R. (1992): Foreign Trade and Economic Reform in China, 1978-1990, Cambridge: Cambridge University Press.

LaU, L. J., Y. Qian, And G. Roland (2000): "Reform without Losers: An Interpretation of China's Dual-Track Approach to Transition," Journal of Political Economy, 108, 120-143.

Li \& Fung Group (2012): What do Expert Say? Ten Highlights of Chinas Commercial Sector, 2011-2012, Li \& Fung Research Centre, available at www.funggroup.com.

Lu, D. (2010): "Exceptional Exporter Performance? Evidence from Chinese Manufacturing Firms," Manuscript, University of Chicago.

Lu, J., Y. Lu, And Z. TAO (2014): "Pure Exporter: Theory and Evidence from China," The World Economy, 37, 1219-1236. 
Manova, K. And Z. Yu (2016): "How Firms Export: Processing vs. Ordinary Trade with Financial Frictions," Journal of International Economics, 100, 120-137.

Mayer, T. And G. Ottaviano (2007): The happy few: the internationalisation of European firms New facts based on firm-level evidence, Brussels: Bruegel.

Melitz, M. J. (2003): "The Impact of Trade on Intra-Industry Reallocations and Aggregate Productivity," Econometrica, 71, 1695-1725.

Melitz, M. J. And G. I. P. Ottaviano (2008): "Market Size, Trade, and Productivity," Review of Economic Studies, 75, 295-316.

Melitz, M. J. And S. J. Redding (2015): "New Trade Models, New Welfare Implications," American Economic Review, 105, 1105-46.

Miranda, M. J. And P. L. Fackler (2004): Applied Computational Economics and Finance, The MIT Press.

Miyagiwa, K. F. (1986): "A Reconsideration of the Welfare Economics of a Free-trade Zone," Journal of International Economics, 21, 337-350.

Munch, J. R. And D. X. Nguyen (2014): "Decomposing Firm-level Sales Variation," Journal of Economic Behavior \& Organization, 106, 317-334.

Naughton, B. (1996): "China's Emergence and Prospects as a Trading Nation," Brookings Papers on Economic Activity, 27, 273-344.

(2007): The Chinese Economy: Transitions and Growth, Cambridge, MA: MIT Press.

Prasad, E. And S.-J. Wei (2007): "The Chinese Approach to Capital Inflows: Patterns and Possible Explanations," in Capital Controls and Capital Flows in Emerging Economies: Policies, Practices and Consequences, ed. by S. Edwards, Chicago, IL: Chicago University Press.

RoDRIK, D. (1987): "The Economics of Export-Performance Requirements," The Quarterly Journal of Economics, 102, 633-50.

- (2010): "Making Room for China in the World Economy," American Economic Review, 100, 89-93.

(2014): "When Ideas Trump Interests: Preferences, Worldviews, and Policy Innovations," Journal of Economic Perspectives, 28, 189-208.

Schminke, A. And J. van Biesebroeck (2011): "Using Export Market Performance to Evaluate Regional Preferential Policies in China," Center for Economic Studies Discussion Paper 11.33, Katholieke Universiteit Leuven.

Song, Z., K. Storesletten, And F. Zilibotti (2011): "Growing Like China," American Economic Review, 101, 196-233.

Standard Chartered Bank (2007): "On the Ground, China," Standard chartered research paper.

WANG, J. (2013): "The Economic Impact of Special Economic Zones: Evidence from Chinese Municipalities," Journal of Development Economics, 101, 133-147. 
Wang, Z. And Z. Yu (2012): "Trading Partners, Traded Products, and Firm Performance: Evidence from China's Exporter-Importers," The World Economy, 35, 1795-1824.

Waters, J. J. (2013): "Achieving World Trade Organization Compliance for Export Processing Zones while Maintaining Economic Competitiveness for Developing Countries," Duke Law Review, 63, 481-524.

World BANK (2013): China 2030: Building a Modern, Harmonious, and Creative Society, Washington, DC: World Bank.

(2014): How to Sustain Export Dynamism by Reducing Duality in the Dominican Republic, Washington, DC: World Bank.

Xu, C. (2011): "The Fundamental Institutions of China's Reforms and Development," Journal of Economic Literature, 49, 1076-1151. 


\section{Subsidies with Export Share Requirements in China Appendix}

\section{A Data used to Construct Figures 1 and 2}

Figure 1 is constructed using data from the annual survey of Chinese manufacturing firms compiled by the National Bureau of Statistics (NBS). Figure 2, requires merging the NBS firm-level survey with transaction-level customs data from the Chinese General Administration of Customs in order to identify firms which based on their type, location and export intensity are more likely to be eligible to receive subsidies with ESR.

The NBS firm-level data includes state-owned enterprises and private firms with sales above 5 million Chinese Yuan; it contains detailed balance sheet information as well as firms' ownership status and total export sales. Firms in the survey account for approximately $95 \%$ of China's industrial output and $98 \%$ of its manufacturing exports.

The unit of observation in the NBS manufacturing survey is the firm, i.e. a legal unit (faren danwei). These need to satisfy the following requirements to be included in the survey: (i) be established legally, having their own names, organization, location and being able to take civil liabilities; (ii) possess and use their assets independently, assume liabilities and be entitled to sign contracts with other units; and (iii) be financially independent and compile their own balance sheets (Brandt et al., 2014). This is the same level of aggregation at which the subsidies with ESR we document in the paper are defined.

Using the firm as our unit of analysis means that all variables of interest are calculated at the firm-level. For instance, the export intensity of multi-plant firms is calculated using total exports and total sales across all establishments that belong to the same firm, which is coherent with the subsidies being defined at the firm- rather than at the establishment-level. Multi-plant firms, however, constitute a minority in the NBS manufacturing survey; Brandt et al. (2012) document that single-plant firms account for more than $95 \%$ of the observations in the NBS manufacturing survey over the 1998-2007 period.

While the NBS data records firms' ownership status and their headquarters' physical address (which we use to determine if a firm is foreign-owned and whether it is located in a FTZ), it does not directly identify processing trade enterprises (PTE), because it does not record the value of exports sold through different customs regimes. To obtain information about a firm's reliance on processing exports, we merge the NBS dataset with transaction-level customs data.

We follow the procedure to clean the data and rule out outliers proposed by Brandt et al. (2012). We drop observations that report missing, null or negative values for total output, employment, intermediate inputs, fixed capital, value-added or if export intensity is greater than 1. We also exclude firms with operation status recorded as 'inactive', 'bankrupt' or 'closed'. Lastly, we drop a small number of observations in which firms report zero exports in the manufacturing survey but that show positive export transactions in the customs data for that particular year. In order to ensure a coherent and comparable industry classification over time, we use the industry concordances suggested by Brandt et al. (2012).

Table A.1 presents summary statistics for the NBS firm-level and matched data. After cleaning the data, the NBS firm-level sample consists of 1,100,600 firm-year observations with exporting firms accounting for $28 \%$ of observations. We follow Manova and Yu (2016) and match the firmlevel and customs data using firms' names as a common variable. By doing so, we are able to match approximately half of the observations reporting a positive value of exports in the NBS sample with their respective customs records. A detailed description of the matching procedure is provided in 
the appendix of Wang and Yu (2012). Although each dataset uses different firm identifiers, a firm's name is a reliable matching variable because by law two firms are not allowed to have the same name in the same administrative region. Matched firms account for $47 \%$ of export volume for 2002-2006. Despite the loss of a large number of observations for exporters in the matching process, Table A.1 below, shows that the export intensity distribution of our matched sample is almost identical to that produced by the NBS data. ${ }^{39}$

Table A.1: Summary Statistics

\begin{tabular}{lccccc}
\hline \hline & \multicolumn{2}{c}{ NBS Manufacturing Survey, 2000-2006 } & & \multicolumn{2}{c}{ Matched Data, 2000-2006 } \\
\cline { 2 - 3 } & $\begin{array}{c}\text { Number of } \\
\text { observations }\end{array}$ & Percentage & & $\begin{array}{c}\text { Number of } \\
\text { observations }\end{array}$ & Percentage \\
Domestic firms & 793,494 & 72.10 & & 793,494 & 83.90 \\
Exporting firms & 307,106 & 27.90 & & 152,217 & 16.10 \\
\hline Total & $1,100,600$ & 100 & 945,711 & 100 \\
\hline \hline
\end{tabular}

Firm Type and Location. We classify firms as processing trade enterprises based on their reliance on the processing regime to sell abroad. We find that the distribution of the export processing intensity exhibits a clear bimodal pattern: $72.1 \%$ of exporters use the processing regime for less than $10 \%$ of their export sales, while $15.5 \%$ sell more than $90 \%$ of their exports through processing. Thus, we define Processing Trade Enterprises (PTE) as firms selling more than 90\% of their exports through processing trade. Based on this definition, PTEs may include firms that export all their output as well as firms selling domestically and abroad. Next, we identify Foreign-Invested Enterprises (FIE) as firms with a positive amount of foreign capital but that do not satisfy the conditionds to be considered PTEs, and Firms located in a Free Trade Zone (FTZ), which are firms situated in prefecture-level cities in which Special Economic Zones, Coastal Development Zones or that belong to the Yangtze and Pearl River Delta Economic Zones have been established. Our definition of FTZ excludes smaller industrial parks such as Economic and Technological Development Zones, New and High-Tech Industrial Development Zones and Export Processing Zones, which also benefit from preferential treatment subject to ESR. Many of these have been set up along the coastline within prefecture-level cities already classified as FTZ in our definition. ${ }^{40}$ Based on their location, ownership and customs status, more than $90 \%$ of all exporters in our matched sample are likely to be eligible to receive subsidies with ESR. See Defever and Riaño (2016a) for an overview on Chinese high-intensity exporters using this data.

\footnotetext{
${ }^{39}$ Bernard et al. (2012) document a substantial level of "carry-along" trade by Belgian manufacturers, i.e. manufacturing firms exporting goods that they do not produce. The NBS data provides information on firms' "total value of sales" and "total value of production sold", which allows us to identify firms engaged in carry-along trade as those for which the value of sales is greater than the total value of their production sold. Reassuringly, excluding carry-along traders from the sample used to construct Figures 1 and 2, leaves figures almost unaffected.

${ }^{40}$ Using a word search on firms' addresses, Schminke and van Biesebroeck (2011) report 891 new firms established in "Economic and Technological Development Zones" between 1999 and 2005, and 47\% of them were located either in the Yangtze or Pearl River Delta Economic zone, already accounted as a FTZ in our definition. Tracking firms located in an "Export Processing Zone" in our data is easier since the customs data provides a special coding identifying them. However, in 2006, only 166 firms can be classified as being located in any of these zones, and among them, $85 \%$ are located in a city which is already classified as a FTZ in our definition.
} 


\section{B List of Free Trade Zones}

Special Economic Zones: They include six prefectures: Haikou, Sanya, Shantou Shi, Shenzhen, Xiamen, Zhuhai and the entire province of Hainan.

Coastal Development Zones: They include the Shanghai Economic area established in 1982. This zone does not cover entirely the Shanghai prefecture, and does not include the city center of Shanghai. We make use of firm's postcode to exclude firms located in the city center from our definition of FTZ, i.e. postcodes starting with "2000".

Coastal Development Zones also include the prefecture-cities of Anshan, Baoding, Beihai, Dalian, Dandong, Fuzhou, Guangzhou, Jinan, Langfang, Lianyungang, Nantong, Ningbo, Qingdao, Qinhuangdao, Quanzhou, Shenyang, Shijiazhuang, Tianjin, Weifang, Wenzhou, Weihai, Yantai, Yingkou, Zhanjiang, Zhangzhou, Zibo.

Yangtze River Delta Economic Zone: It includes cities located in the Yangtze River Delta but also some cities located outside the area due to mutual economic development. In 1982, the Chinese government set up the Shanghai Economic Area. Besides Shanghai, 4 cities in Jiangsu (Changzhou, Nantong, Suzhou, Wuxi) and 5 cities in Zhejiang (Hangzhou, Huzhou, Jiaxing, Ningbo, Shaoxing) were included. In 1992, a 14-city cooperative joint meeting was launched. Besides the previous 10 cities, the members included Nanjing, Yangzhou and Zhenjiang in Jiangsu, and Zhoushan in Zhejiang. In 1998, Taizhou became a new member.

Pearl River Delta Economic Zone: The boundaries of the Pearl River Delta economic zone differ from those associated with the geographic boundaries of the delta. In 1985, the State Council designated the Pearl River Delta as an open economic zone. It contained three Special Economic Zones that were established earlier: Shantou, Shenzhen and Zhuhai. Other leading cities in the open zone are: Dongguan, Foshan, Guangzhou, Huizhou, Jiangmen and Zhongshan. 'Peripheral' cities that were declared open cities include: Chaozhou, Heyuan, Jieyang, Maoming, Meizhou, Qingyuan, Shanwei, Shaoguan, Yangjiang, Zhanjiang and Zhaoqing.

Figure B.1: Free Trade Zones Established Between 1979 and 2000

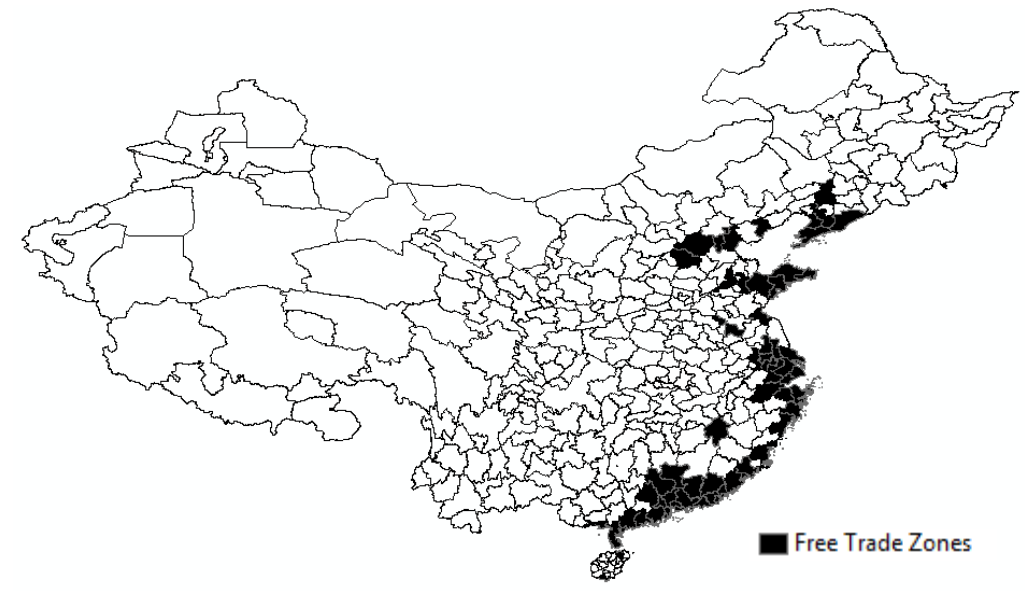




\section{Proof of Proposition 1}

The Lagrangian associated with problem (8) is given by:

$$
\begin{gathered}
\mathcal{L}=\sum_{j \in\{H, F\}}\left\{\left[\left(1+s_{r}\right) A_{H j}^{\frac{1}{\sigma}}(\omega)\left(q_{H j}(\omega)\right)^{-\frac{1}{\sigma}}-\left(\frac{w_{H} \tau_{H j}}{\varphi}\right)\right] q_{H j}(\omega)-w_{H} f_{H j}\right\} \cdot 1_{H j}(\omega)- \\
\lambda_{\eta} \cdot\left[\underline{\eta}-\frac{A_{H F}^{\frac{1}{\sigma}}(\omega)\left(q_{H F}(\omega)\right)^{\frac{\sigma-1}{\sigma}}}{A_{H H}^{\frac{1}{\sigma}}(\omega)\left(q_{H H}(\omega)\right)^{\frac{\sigma-1}{\sigma}}+A_{H F}^{\frac{1}{\sigma}}(\omega)\left(q_{H F}(\omega)\right)^{\frac{\sigma-1}{\sigma}}}\right]-\lambda_{d} \cdot q_{H H}(\omega)-\lambda_{x} \cdot q_{H F}(\omega),
\end{gathered}
$$

where $\lambda_{\eta}, \lambda_{d}$ and $\lambda_{x}$ are the Lagrange multipliers associated with the export share requirement constraint and domestic and export quantities respectively. The first-order conditions (where we have omitted the dependence of quantities and demand shifters on $\omega$ to avoid clutter) with respect to $q_{H H}, q_{H F}$ and $\lambda_{\eta}$ are given by:

$$
\begin{aligned}
& \left(\frac{\sigma}{\sigma-1}\right) A_{H H}^{\frac{1}{\sigma}} q_{H H}^{-\frac{1}{\sigma}}\left\{\left(1+s_{r}\right)-\lambda_{\eta}\left[\frac{A_{H F}^{\frac{1}{\sigma}} q_{H F}^{\frac{\sigma-1}{\sigma}}}{\left(A_{H H}^{\frac{1}{\sigma}} q_{H H}^{\frac{\sigma-1}{\sigma}}+A_{H F}^{\frac{1}{\sigma}} q_{H F}^{\frac{\sigma-1}{\sigma}}\right)^{2}}\right]\right\}-\left(\frac{w_{H}}{\varphi}\right)-\lambda_{d} \leqslant 0, \quad\left(=0 \text { if } q_{H H}>0\right) \\
& \left(\frac{\sigma}{\sigma-1}\right) A_{H F}^{\frac{1}{\sigma}} q_{H F}^{-\frac{1}{\sigma}}\left\{\left(1+s_{r}\right)-\lambda_{\eta}\left[\frac{A_{H H}^{\frac{1}{\sigma}} q_{H H}^{\frac{\sigma-1}{\sigma}}}{\left(A_{H H}^{\frac{1}{\sigma}} \frac{\frac{\sigma-1}{\sigma}}{q_{H H}}+A_{H F}^{\frac{1}{\sigma}} q_{H F}^{\frac{\sigma-1}{\sigma}}\right)^{2}}\right]\right\}-\left(\frac{\tau_{H F} w_{H}}{\varphi}\right)-\lambda_{x} \leqslant 0, \quad\left(=0 \text { if } q_{H F}>0\right)
\end{aligned}
$$

$$
\frac{A_{H F}^{\frac{1}{\sigma}} q_{H F}^{\frac{\sigma-1}{\sigma}}}{A_{H H}^{\frac{1}{\sigma}} q_{H H}(\omega)^{\frac{\sigma-1}{\sigma}}+A_{H F}^{\frac{1}{\sigma}} q_{H F}^{\frac{\sigma-1}{\sigma}}} \geqslant \underline{\eta} .
$$

Firstly, note that for the export share requirement constraint to be satisfied it is necessary that $q_{H F}>0$. This in turn implies that $\lambda_{x}=0$ in all candidate solutions. Secondly, if the firm chooses not to sell at all in domestic market $\left(q_{H H}=0\right.$ and therefore $\left.\lambda_{d}>0\right)$ then, its export intensity is equal to 1 and therefore $\lambda_{\eta}=0$. This leaves us with three candidate solutions to problem (8), which in turn define three types of firms operating subject to the export share requirement $\underline{\eta}$ :

1. Constrained regular exporter: The export share requirement is satisfied with equality $\left(\lambda_{\eta}>0\right)$. This implies that both $q_{H H}$ and $q_{H F}$ are strictly positive $\left(\lambda_{d}=0\right)$ as long as $\underline{\eta}<1$.

2. Unconstrained regular exporter: The export intensity constraint is not binding $\left(\lambda_{\eta}=0\right)$ and the firm sells in both markets, and,

3. Pure exporter: The firm chooses to export all its output. In this case $\lambda_{\eta}=0$ and $\lambda_{d}>0$. 


\section{Constrained regular exporter}

As noted above, in this case, equations (C.2)-(C.4) hold with equality. Substituting (C.4) into (C.2) and (C.3), yields the following solution for the quantities sold in Home and Foreign:

$$
\begin{gathered}
q_{H H}=A_{H H}\{\underbrace{\left.\left[\frac{(1-\underline{\eta})^{\frac{\sigma}{\sigma-1}} A_{H F}^{\frac{1}{\sigma-1}}+\underline{\eta}^{\frac{\sigma}{\sigma-1}} \tau_{H F} A_{H H}^{\frac{1}{\sigma-1}}}{(1-\underline{\eta})^{\frac{1}{\sigma-1}} A_{H F}^{\frac{1}{\sigma-1}}}\right] \frac{\sigma}{\sigma-1} \cdot \frac{1}{1+s_{r}} \cdot \frac{w_{H}}{\varphi}\right\}^{-\sigma},}_{=p_{H H}} \\
q_{H F}=A_{H F}\left\{[\underbrace{\left[\frac{(1-\underline{\eta})^{\frac{\sigma}{\sigma-1}} A_{H F}^{\frac{1}{\sigma-1}}+\underline{\eta}^{\frac{\sigma}{\sigma-1}} \tau_{H F} A_{H H}^{\frac{1}{\sigma-1}}}{\underline{\eta}^{\frac{1}{\sigma-1}} A_{H H}^{\frac{1}{\sigma-1}}}\right] \frac{\sigma}{\sigma-1} \cdot \frac{1}{1+s_{r}} \cdot \frac{w_{H}}{\varphi}}_{=p_{H F}}\}^{-\sigma} .\right.
\end{gathered}
$$

We also need to verify that (C.5) and (C.6) imply $\lambda_{\eta}>0$. Solving for $\lambda_{\eta}$ in equation (C.2) yields the following expression:

$$
\lambda_{\eta}=\frac{A_{H H}^{\frac{1}{\sigma}} q_{H H}^{\frac{\sigma-1}{\sigma}}+A_{H F}^{\frac{1}{\sigma}} q_{H F}^{\frac{\sigma-1}{\sigma}}}{\underline{\eta}} \cdot\left[\left(1+s_{r}\right)-\frac{\sigma}{\sigma-1} \cdot \frac{w_{H}}{\varphi} \cdot\left(\frac{q_{H H}}{A_{H H}}\right)^{\frac{1}{\sigma}}\right] .
$$

Thus, it follows that for $\lambda_{\eta}>0$ we need the expression in square brackets to be positive. Substituting (C.5) into the term in square brackets in equation (C.7), yields,

$$
\left(1+s_{r}\right)\left[1-\frac{(1-\underline{\eta})^{\frac{1}{\sigma-1}} A_{H F}^{\frac{1}{\sigma-1}}}{(1-\underline{\eta})^{\frac{\sigma}{\sigma-1}} A_{H F}^{\frac{1}{\sigma-1}}+\underline{\eta}^{\frac{\sigma}{\sigma-1}} \tau_{H F} A_{H H}^{\frac{1}{\sigma-1}}}\right] .
$$

Simplifying (C.8) further, shows that $\lambda_{\eta}>0$ when $\frac{\tau_{H F}^{1-\sigma} A_{H F}}{A_{H H}+\tau_{H F}^{1-\sigma} A_{H F}}<\underline{\eta}$.

Substituting (C.5) and (C.6) into the profit function (8), yields the profit for a constrained regular exporter:

$$
\pi_{H}^{d x c}(\omega)=\kappa\left(1+s_{r}\right)^{\sigma} \Theta(\underline{\eta})\left(\varphi / w_{H}\right)^{\sigma-1}-\left(f_{H H}+f_{H F}\right) w_{H},
$$

where $\Theta$ is a profit-shifter term given by:

$$
\Theta=\frac{A_{H H} A_{H F}}{\left[(1-\underline{\eta})^{\frac{\sigma}{\sigma-1}} A_{H F}^{\frac{1}{\sigma-1}}+\underline{\eta}^{\frac{\sigma}{\sigma-1}} \tau_{H F} A_{H H}^{\frac{1}{\sigma-1}}\right]^{\sigma-1}} .
$$

It is straightforward to verify that $\Theta(0)=A_{H H}$ and $\Theta(1)=\tau_{H F}^{1-\sigma} A_{H F}$.

We now establish that $\Theta$ is maximized at a firm's natural export intensity, $\eta_{H}^{d x}$.

$\frac{\mathrm{d} \Theta}{\mathrm{d} \underline{\eta}}=-\sigma\left(A_{H H} A_{H F}\right)\left[(1-\underline{\eta})^{\frac{\sigma}{\sigma-1}} A_{H F}^{\frac{1}{\sigma-1}}+\underline{\eta}^{\frac{\sigma}{\sigma-1}} \tau_{H F} A_{H H}^{\frac{1}{\sigma-1}}\right]^{-\sigma} \cdot\left(-(1-\underline{\eta})^{\frac{1}{\sigma-1}} A_{H F}^{\frac{1}{\sigma-1}}+\tau_{H F} \underline{\eta}^{\frac{1}{\sigma-1}} A_{H H}^{\frac{1}{\sigma-1}}\right)=0$, 
Solving for $\underline{\eta}$ in (C.11) yields:

$$
\underline{\eta}^{*}=\frac{\tau_{H F}^{1-\sigma} A_{H F}}{A_{H H}+\tau_{H F}^{1-\sigma} A_{H F}}=\eta_{H}^{d x} .
$$

Substituting (C.12) into (C.10) verifies that $\Theta\left(\eta_{H}^{d x}\right)=A_{H H}+\tau_{H F}^{1-\sigma} A_{H F}$. The second-order sufficient condition reads:

$$
\begin{aligned}
\frac{\mathrm{d}^{2} \Theta}{\mathrm{d} \underline{\eta}^{2}}= & -\frac{\sigma}{\sigma-1}\left(A_{H H} A_{H F}\right)\left\{\sigma \left(\tau_{H F} \underline{\eta}^{\frac{1}{\sigma-1}} A_{H H}^{\frac{1}{\sigma-1}}-\left(1-\underline{\eta}^{\frac{1}{\sigma-1}} A_{H F}^{\frac{1}{\sigma-1}}\right)^{2}+\right.\right. \\
& \left.\left(\tau_{H F} \underline{\eta}^{\frac{\sigma}{\sigma-1}} A_{H H}^{\frac{1}{\sigma-1}}+(1-\underline{\eta})^{\frac{\sigma}{\sigma-1}} A_{H F}^{\frac{1}{\sigma-1}}\right) \cdot\left(\tau_{H F} \underline{\eta}^{\frac{2-\sigma}{\sigma-1}} A_{H H}^{\frac{1}{\sigma-1}}+(1-\underline{\eta})^{\frac{2-\sigma}{\sigma-1}} A_{H F}^{\frac{1}{\sigma-1}}\right)\right\}<0,
\end{aligned}
$$

which proves that $\Theta$ is a concave function of $\underline{\eta}$, and therefore, that $\underline{\eta}^{*}$ is a global maximum.

\section{Unconstrained regular exporter}

In this case $\lambda_{\eta}=\lambda_{d}=\lambda_{x}=0$. Solving for $q_{H H}$ and $q_{H F}$ in the FOC (C.2) and (C.3) results in:

$$
\begin{aligned}
& q_{H H}=A_{H H}\left[\frac{\sigma}{\sigma-1} \cdot \frac{1}{1+s_{r}} \cdot \frac{w_{H}}{\varphi}\right]^{-\sigma}, \\
& q_{H F}=A_{H F}\left[\frac{\sigma}{\sigma-1} \cdot \frac{1}{1+s_{r}} \cdot \frac{\tau_{H F} w_{H}}{\varphi}\right]^{-\sigma} .
\end{aligned}
$$

These are the same quantities that an exporting firm would choose if the sales subsidy $s_{r}$ was not subject to an ESR. To be consistent with our assumption that the export share requirement is not binding, it is necessary that $\frac{\tau_{H F}^{1-\sigma} A_{H F}}{A_{H H}+\tau_{H F}^{1-\sigma} A_{H F}}>\underline{\eta}$.

Firm's profits for unconstrained regular exporters are:

$$
\pi_{H}^{d x u}(\omega)=\kappa\left(1+s_{r}\right)^{\sigma}\left(A_{H H}+\tau_{H F}^{1-\sigma} A_{H F}\right)\left(\varphi / w_{H}\right)^{\sigma-1}-\left(f_{H H}+f_{H F}\right) w_{H} .
$$

\section{Pure exporter}

In this case $\lambda_{\eta}=0$ and $\lambda_{d}>0$. It follows straightforwardly that the optimal quantity sold abroad is:

$$
q_{H F}=A_{H F}\left[\frac{\sigma}{\sigma-1} \cdot \frac{1}{1+s_{r}} \cdot \frac{\tau_{H F} w_{H}}{\varphi}\right]^{-\sigma}
$$

and profits are:

$$
\pi_{H}^{x}(\omega)=\kappa\left(1+s_{r}\right)^{\sigma} \tau_{H F}^{1-\sigma} A_{H F}\left(\varphi / w_{H}\right)^{\sigma-1}-f_{H F} w_{H}
$$

From FOC (C.2) it follows that the complementary slackness condition $\left(1+s_{r}\right)\left(\frac{\sigma}{\sigma-1}\right)\left(\frac{A_{H H}}{q_{H H}}\right)^{\frac{1}{\sigma}}-$ $\left(w_{H} / \varphi\right)-\lambda_{d}>0$ is satisfied since the first term tends to infinity when $q_{H H} \rightarrow 0$. 
A firm that chooses to operate facing the export share requirement $\underline{\eta}$ chooses the type that yields the highest profit. Thus,

$$
\pi_{H}^{\mathrm{ESR}}(\omega)=\max \left\{\pi_{H}^{d x c}(\omega), \pi_{H}^{d x u}(\omega), \pi_{H}^{x}(\omega)\right\}
$$

By comparing the profits for each type we can characterize a firm's choice based on its state vector, namely, its productivity $\varphi$ and realized demand shifters $z_{H H}$ and $z_{H F}$.

The comparison between constrained and unconstrained regular exporters is entirely determined by a firm's natural export intensity: A firm with a natural export intensity below $\eta$ would set prices so as to achieve an export intensity exactly equal to $\underline{\eta}$ if it were to operate subject to the ESR. On the other hand, a firm with natural export intensity above $\underline{\eta}$ prefers to maintain its natural export intensity, and therefore operates as an unconstrained regular exporter.

For a firm to operate as a constrained regular exporter it also needs to find this option preferable than being a pure exporter. This is the case when,

$$
\varphi \geqslant \varphi^{d x c}\left(\omega ; \underline{\eta}, s_{r}\right) \equiv\left[\frac{w_{H}^{\sigma} f_{H H}}{\kappa\left(1+s_{r}\right)^{\sigma}\left(\Theta(\omega, \underline{\eta})-\tau_{H F}^{1-\sigma} A_{H F}\right)}\right]^{\frac{1}{\sigma-1}} .
$$

Similarly, a firm with natural export intensity above $\underline{\eta}$ prefers to sell in both markets than being a pure exporter if,

$$
\varphi \geqslant \varphi^{d x u}\left(\omega ; s_{r}\right) \equiv\left[\frac{w_{H}^{\sigma} f_{H H}}{\kappa\left(1+s_{r}\right)^{\sigma} A_{H H}}\right]^{\frac{1}{\sigma-1}} .
$$

Thus, for given realizations of demand shifters (and therefore, of a firm's natural export intensity), more productive firms are more likely to sell in both markets (satisfying the ESR constraint) than to operate as pure exporters. Similarly, a higher subsidy rate $s_{r}$ increases the attractiveness of being a regular exporter. Operating as a pure exporter, on the other hand, is more likely the higher the domestic fixed cost $f_{H H}$ is.

\section{Corollary 1}

A constrained regular exporter receiving subsidies with ESR sets a higher price domestically and a lower price in the foreign market than if the ESR were not binding.

Proof. This result follows directly from the fact that the terms in square brackets in equations (C.5) and (C.6) are respectively greater than 1 and lower than $\tau_{H F}$ if $\eta_{H}^{*}(\omega)<\underline{\eta}$. 


\section{Coexistence of Production Modes}

In this Appendix, we show that all five types of firms coexist for any given level of productivity taking as given the level of aggregate variables, i.e. aggregate income and the price index.

Let us first consider a situation in which both $z_{H H}$ and $z_{H F}$ are sufficiently high relative to the fixed costs of operation so that a firm $\omega$ would, given a level of productivity $\bar{\varphi}$, sell both in Home and Foreign. Proposition 1 shows that firms subject to the ESR would operate either as constrained regular exporters, if their export intensity when selling in both markets, $\eta_{H}^{*}(\omega)$, is below $\underline{\eta}$, or as unconstrained regular exporters otherwise. Firms with a natural export intensity that exceeds the ESR threshold do not have an incentive to operate as anything other than as regular unconstrained exporters, since other production modes would entail either lowering profits by not operating at the firm's natural export intensity and/or foregoing the subsidy.

The more interesting comparison arises between firms that face the choice between operating as constrained regular exporters - distorting their export intensity but enjoying the subsidy — or, as regular exporters not facing the ESR and operating at their natural export intensity. A direct profit comparison between the two modes of production, reveals that a firm $\omega$ would be indifferent between the two, if the subsidy rate is equal to:

$$
\bar{s}_{r}=\left(\frac{A_{H H}(\omega)+\tau_{H F}^{1-\sigma} A_{H F}(\omega)}{\Theta(\omega, \underline{\eta})}\right)^{\frac{1}{\sigma}}-1 .
$$

Using the fact that $A_{H H}(\omega)=\left(\frac{1-\eta_{H}^{*}(\omega)}{\eta_{H}^{*}(\omega)}\right) \tau_{H F}^{1-\sigma} A_{H F}(\omega)$, and plugging this back into (D.1), we obtain:

$$
\bar{s}_{r}=\left(\frac{(1-\underline{\eta})^{\frac{\sigma}{\sigma-1}}}{\left(1-\eta_{H}^{*}(\omega)\right)^{\frac{1}{\sigma-1}}}+\frac{\underline{\eta}^{\frac{\sigma}{\sigma-1}}}{\eta_{H}^{*}(\omega)^{\frac{1}{\sigma-1}}}\right)^{\frac{1}{\sigma}}-1 .
$$

Note that the magnitude of the subsidy rate $\bar{s}_{r}$ does not depend on the level of demand shifters or productivity, but only on the export intensity that a firm would choose if it sold its output in both markets, $\eta_{H}^{*}(\omega)$. It follows straightforwardly from (D.2) that $\bar{s}_{r} \rightarrow 0$ when $\eta_{H}^{*}(\omega) \rightarrow \eta$, and, $\bar{s}_{r} \rightarrow \infty$ when $\eta_{H}^{*}(\omega) \rightarrow 0$. This means that, given a subsidy rate $s_{r}$, there is an export intensity $\widehat{\eta}\left(s_{r}\right) \in(0, \eta]$ such that firms with $\eta_{H}^{*}(\omega) \in\left[\widehat{\eta}\left(s_{r}\right), \eta\right)$ prefer to operate as constrained regular exporters than to produce at their natural export intensity and not receiving the subsidy $s_{r}$. Thus, when demand shifters are high enough for a firm to operate profitably in both markets, there are three types of firms operating at any given level of productivity; regular exporters not subject to ESR, constrained regular exporters and unconstrained regular exporters. We can write the profits of a Home firm selling in both markets as,

$$
\pi_{H}(\omega)=\kappa \mathbf{A}_{\mathbf{H}}(\omega)\left(\varphi / w_{H}\right)^{\sigma-1}-w_{H}\left(f_{H H}+f_{H F}\right)
$$

where,

$$
\mathbf{A}_{\mathbf{H}}(\omega)=\left\{\begin{array}{l}
\left(1+s_{r}\right)^{\sigma}\left(A_{H H}(\omega)+\tau_{H F}^{1-\sigma} A_{H F}(\omega)\right), \quad \text { if } \eta_{H}^{*}(\omega) \geqslant \underline{\eta} \\
\left(1+s_{r}\right)^{\sigma} \Theta(\omega, \underline{\eta}), \quad \text { if } \eta_{H}^{*}(\omega) \in\left[\widehat{\eta}\left(s_{r}\right), \underline{\eta}\right), \\
A_{H H}(\omega)+\tau_{H F}^{1-\sigma} A_{H F}(\omega), \quad \text { if } \eta_{H}^{*}(\omega) \in\left(0, \widehat{\eta}\left(s_{r}\right)\right) .
\end{array}\right.
$$

Let us now consider the case in which a firm's demand in one market might not be sufficiently high to guarantee positive profits. Under these circumstances, a firm might find optimal to operate domestically or as a pure exporter. For a given productivity level, consider a firm with domestic 
demand shifter $z_{H H}>z_{H H}^{*}$, with $z_{H H}^{*}$ as defined above; this firm would therefore earn positive profits if it sold its output in the domestic market alone. This firm would also prefer operate domestically rather than in both markets, if:

$$
\frac{w_{H}^{\sigma} f_{H F}}{\kappa\left(\bar{\varphi}^{\sigma-1}\right)} \geqslant \mathbf{A}_{\mathbf{H}}(\omega)-A_{H H}(\omega)
$$

Notice that when $z_{H F} \rightarrow 0$, then $\eta_{H}^{*}(\omega) \rightarrow 0$ and therefore $\mathbf{A}_{\mathbf{H}}(\omega) \rightarrow A_{H H}(\omega)$, which implies that condition (D.5) holds. Moreover, as $z_{H F} \rightarrow 0$ it follows that the gross profit from operating as a pure exporter goes to zero as well.

Now consider a firm that draws its export demand shifter above $z_{H F}^{*} /\left(1+s_{r}\right)^{\sigma}$, and thus can earn positive profits by only exporting. Such a firm would prefer to operate as a pure rather than as a regular exporter if:

$$
\frac{w_{H}^{\sigma} f_{H H}}{\kappa\left(\bar{\varphi}^{\sigma-1}\right)} \geqslant \mathbf{A}_{\mathbf{H}}(\omega)-\left(1+s_{r}\right)^{\sigma} \tau_{H F}^{1-\sigma} A_{H F}(\omega)
$$

When $z_{H H} \rightarrow 0$, then $\mathbf{A}_{\mathbf{H}}(\omega) \rightarrow\left(1+s_{r}\right)^{\sigma} \tau_{H F}^{1-\sigma} A_{H F}(\omega)$, and therefore, condition (D.6) is satisfied. Since $z_{H H} \rightarrow 0$ it follows that gross profits of operating domestically are not sufficient to cover the fixed cost $w_{H} f_{H H}$.

This implies that for a given level of productivity, firms that simultaneously draw a low export demand shifter, but a sufficiently high domestic one (in the sense of allowing them to earn positive profits by operating domestically) choose to operate as domestic firms. In the opposite situation, firms prefer to operate as pure exporters instead. Firms that draw relatively high demand shifters both domestically and abroad sort themselves either operating under ESR or not depending on their natural export intensity. 


\section{E Solution Algorithm}

In this section we outline the algorithm used to solve the general equilibrium model presented in Section 3. Recall that we have assumed in our benchmark that both countries are identical in terms of preferences, endowments and the distributions of productivity and demand shifters as well as the parameters governing these objects.

1. Approximate the distributions of firm-destination-specific demand shifters using the Gaussian quadrature procedure described in Miranda and Fackler (2004). This produces grids $Z_{i i}=$ $\left[z_{i i, 1}, \ldots, z_{i i, N_{z}}\right]$ and $Z_{i j}=\left[z_{i j, 1}, \ldots, z_{i j, N_{z}}\right]$, as well as cumulative density functions $F_{z_{i i}}$ and $F_{z_{i j}}$, where $i, j \in\{H, F\}$, so that domestic and export demand shifters are log-normally distributed with underlying parameters $\left(\mu_{d}, \sigma_{d}^{2}\right)$ and $\left(\mu_{x}, \sigma_{x}^{2}\right)$ respectively. We set $N_{z}=25$ when solving the model.

2. For each possible combination of domestic and export demand shifters $\left(z_{i i}, z_{i j}\right)$, determine the minimum productivity level necessary for a firm at Home to achieve non-negative profits in each of the modes of operation available. At Home (when it offers subsidies with ESR) these are: domestic $(d)$, regular exporter not subject to $\operatorname{ESR}(d x)$, constrained regular exporter $(d x c)$, unconstrained regular exporter $(d x u)$ and pure exporter $(x)$. At Foreign, the modes of operation available are: domestic, regular exporter and pure exporter. The minimum productivity necessary for a firm of type $k$ in country $i$ to operate profitably is given by:

$$
\varphi_{i}^{*}\left(z_{i i}, z_{i j}\right)=\min _{k}\left\{\varphi_{i}^{*, k}\right\}
$$

where $\varphi_{i}^{*, k}=\left\{\varphi: \pi_{i}^{k}\left(\varphi ; z_{i i}, z_{i j}\right)=0\right\}$.

3. For each $\varphi_{i}^{*}\left(z_{i i}, z_{i j}\right)$, approximate the Pareto distribution of productivity conditional on survival, i.e. a Pareto distribution with shape parameter $a$ and scale parameter $\varphi_{i}^{*}\left(z_{i i}, z_{i j}\right)$, again using Gaussian quadrature. This produces a productivity grid $\Phi_{i}=\left[\varphi_{1}, \ldots, \varphi_{N_{\varphi}}\right]$ and a cumulative density function $F_{\varphi}$, with $N_{\varphi}=50$. Next, we construct a grid of size $N_{\varphi} \times N_{z}^{2}$ (i.e. 31,250 points) for firms' state vector $\omega_{i}$, given by the tensor product of the productivity and demand shifter grids, $\boldsymbol{\Omega}_{i}=\Phi_{i} \otimes Z_{i i} \otimes Z_{i j}$. Since productivity draws and demand shifters are independent from each other, the corresponding cumulative density function for $\omega \in \boldsymbol{\Omega}_{i}$ is given by $\mathcal{F}_{i}(\omega)=F_{\varphi, i} \otimes F_{z_{i i}} \otimes F_{z_{i j}}$. Notice that when subsidies are in place, the equilibrium is not symmetric and therefore the distribution of productivity differs across countries.

4. For each element $\omega \in \boldsymbol{\Omega}_{i}$, we solve firms' problem, i.e. we determine the production mode $k$ that maximizes profits, and record firms' optimal prices $\left\{p_{i j}^{k}(\omega)\right\}$, quantities $\left\{q_{i j}^{k}(\omega)\right\}$, sales revenue (after subsidies) $\left\{r_{i j}^{k}(\omega)\right\}$, profits $\left\{\pi_{i}^{k}(\omega)\right\}$ and labor demand $\left\{l_{i}^{k}(\omega)\right\}$, in each country $i, j \in\{H, F\}$.

5. The general equilibrium $\left(M_{H}, M_{F}, P_{H}, P_{F}, E_{H}, E_{F}, w_{F}\right)$ of this economy is found as the solution to the following system of 7 non-linear equations:

- Labor market clearing:

$$
M_{i}\left[\sum_{k} \int l_{i}^{k}(\omega) d \mathcal{F}_{i}(\omega)\right]=L_{i}, \quad i \in\{H, F\}
$$


- Free entry:

$$
\left[\iint\left[1-F_{\varphi, i}\left(\varphi^{*}\left(z_{i i}, z_{i j}\right)\right)\right] d F_{z_{i i}}\left(z_{i i}\right) d F_{z_{i j}}\left(z_{i j}\right)\right] \cdot\left[\sum_{k} \int \pi_{i}^{k}(\omega) d \mathcal{F}_{i}(\omega)\right]=w_{i} f_{e}, i \in\{H, F\}
$$

where the first term in brackets on the left hand side of the equation is the probability of operating in country $i$.

- Aggregate income consistency:

$$
E_{i}=w_{i} L_{i}-T_{i}, \quad i \in\{H, F\}
$$

where,

$$
T_{H}=\sum_{k \in\{d x c, d x u, x\}}\left[M_{H}\left\{\frac{s_{r}}{1+s_{r}} \int\left[r_{H H}^{k}(\omega)+r_{H F}^{k}(\omega)\right] \cdot 1_{H}^{k}(\omega) d \mathcal{F}_{H}(\omega)\right\}\right],
$$

and $T_{F}=0 ;$ and,

- Balanced trade:

$$
\begin{array}{r}
M_{H}\left[\int r_{H F}^{d x}(\omega) d \mathcal{F}_{H}(\omega)+\sum_{k \in\{d x c, d x u, x\}} \frac{1}{1+s_{r}} \int r_{H F}^{k}(\omega) \cdot 1_{H}^{k}(\omega) d \mathcal{F}_{H}(\omega)\right]= \\
M_{F}\left[\sum_{k \in\{d x, x\}} \int r_{F H}^{k}(\omega) d \mathcal{F}_{H}(\omega)\right],
\end{array}
$$

where $1_{i}^{k}(\omega)$ is the indicator function taking the value 1 when a firm in country $i$ with state vector $\omega$ uses operation mode $k$.

The solution of the model is not unduly influenced by our choice of starting values for the vector of endogenous variables $\left(M_{h}, M_{f}, P_{h}, P_{f}, E_{h}, E_{f}, w_{f}\right)$ when solving the system of non-linear equations described in equations (E.1)-(E.4). We conduct a Monte Carlo experiment in which, taking as given the model's benchmark parametrization, we drew 10,000 realizations of starting values drawn from seven independent log-normal distributions for which the mean and variance of the underlying normal variable were -2 and 4 respectively (so that the 5 th percentile for each variable is approximately $1 \mathrm{e}-4$ and its 95 th percentile is 97.45 ), thus providing a substantial range of variation and solving for the general equilibrium. Carrying out this exercise both for the laissezfaire and subsidies subject to ESR scenarios reveals that our algorithm always converges to the same equilibrium regardless of the initial conditions. 


\section{F Calibrating the Model Using the Export Intensity Distribution of China in 2013}

In this section we present the model's parameters (Table F.1) and the subsidy comparison results (Table F.2) when the export intensity distribution of China in 2013 (calculated from firm-level data drawn from the World Bank Enterprise Surveys) is used to calibrate the natural export intensity distribution prevailing under laissez-faire.

Table F.1: Parameter Values — China 2013 Export Intensity

\begin{tabular}{lc}
\hline \hline Description & Value \\
\hline \hline Assigned parameters: & \\
Country size $(L)$ & 1 \\
Elasticity of substitution $(\sigma)$ & 3 \\
Shape parameter productivity distribution $(a)$ & 2.713 \\
Scale parameter productivity distribution $(\underline{\varphi})$ & 1 \\
Fixed cost — domestic sales $\left(f^{d}\right)$ & 1 \\
Transport cost $(\tau)$ & 1.7 \\
& \\
Calibrated parameters: & \\
Fixed cost — entry $\left(f^{e}\right)$ & 3.458 \\
Fixed cost - exporting $\left(f^{x}\right)$ & 0.719 \\
Domestic demand shifters $\left(\ln \left(z_{i i}\right) \sim \mathcal{N}\left(\mu_{d}, \sigma_{d}^{2}\right)\right)$ & $(-0.685,1.371)$ \\
Export demand shifters $\left(\ln \left(z_{i j}\right) \sim \mathcal{N}\left(\mu_{x}, \sigma_{x}^{2}\right)\right)$ & $(-1.538,0.898)$ \\
\hline \hline
\end{tabular}


Table F.2: Comparison of Subsidies with respect to Laissez-Faire — China 2013 Export Intensity

\begin{tabular}{lcc}
\hline \hline Variable & $\begin{array}{c}\text { Subsidy with Export } \\
\text { Share Requirements } \\
\end{array}$ & $\begin{array}{c}\text { Unconditional Sales } \\
\text { Subsidy for Exporters } \\
(1)\end{array}$ \\
\cline { 2 - 3 } Wage, Foreign & -6.349 & -1.890 \\
Price index, Home & 2.136 & -0.617 \\
Price index, Foreign & -7.722 & -2.124 \\
Probability of exit, Home & -1.472 & 2.090 \\
Probability of exit, Foreign & -1.091 & -0.255 \\
Welfare, Home & -4.881 & -0.471 \\
Welfare, Foreign & 1.502 & 0.239 \\
Exports/GDP & 13.876 & 1.212 \\
& & \\
Share of Home's exporters & percentage point change w.r.t. laissez-faire \\
with export intensity & & \\
$\quad \in[0.7,1)$ & 15.169 & -0.214 \\
$\quad=1$ & 6.112 & -5.392 \\
\hline \hline
\end{tabular}

$\overline{\text { Column (1) compares an } 8.7 \% \text { ad-valorem subsidy to total sales granted to firms with an }}$ export intensity of at least $70 \%$ with the laissez-faire equilibrium. Column (2) compares a $1.44 \%$ ad-valorem subsidy to total sales made available to all exporting firms regardless of their export intensity with the laissez-faire equilibrium. Both subsidy schemes result in aggregate subsidy expenditure accounting for 1.09\% of Home's GDP. Neither Home nor Foreign conducts any trade policy under laissez-faire, but trade costs in both directions are maintained at their calibrated level (1.7) across all scenarios. 


\section{G Sensitivity Analysis}

Table G.1: Sensitivity Analysis of Model Parameters

\begin{tabular}{|c|c|c|c|c|c|c|c|}
\hline \multirow[t]{3}{*}{ Variable } & \multicolumn{7}{|c|}{ 8.7\% Sales Subsidy with ESR } \\
\hline & \multirow[t]{2}{*}{ Benchmark } & \multicolumn{6}{|c|}{$\Delta 10 \%$ from benchmark parametrization } \\
\hline & & $\sigma$ & $f^{d}$ & $f^{e}$ & $L_{f}$ & $\varphi_{F}$ & $\tau$ \\
\hline & \multicolumn{7}{|c|}{$\%$ change w.r.t. laissez-faire } \\
\hline Wage, Foreign & -3.74 & -3.53 & -3.49 & -3.67 & -3.56 & -3.57 & -2.91 \\
\hline Price index, Home & 0.49 & 0.38 & 0.41 & 0.45 & 0.45 & 0.46 & 0.31 \\
\hline Price index, Foreign & -4.19 & -3.86 & -3.93 & -4.16 & -3.95 & -3.98 & -3.16 \\
\hline Probability of exit, Home & -4.98 & -3.60 & -5.27 & -6.57 & -5.56 & -5.40 & -3.58 \\
\hline Probability of exit, Foreign & -2.16 & -1.13 & -2.23 & -3.78 & -1.90 & -1.95 & -0.56 \\
\hline Welfare, Home & -1.38 & -1.09 & -1.26 & -1.32 & -1.35 & -1.36 & -0.87 \\
\hline Welfare, Foreign & 0.47 & 0.31 & 0.47 & 0.51 & 0.41 & 0.42 & 0.23 \\
\hline \multirow[t]{2}{*}{ Exports/GDP } & 9.32 & 10.14 & 8.47 & 9.32 & 8.69 & 8.91 & 7.27 \\
\hline & \multicolumn{7}{|c|}{ percentage point change w.r.t. laissez-faire } \\
\hline $\begin{array}{l}\text { Share of Home's exporters } \\
\text { with export intensity }\end{array}$ & & & & & & & \\
\hline$\in[0.7,1)$ & 7.88 & 8.16 & 6.68 & 7.40 & 7.31 & 7.80 & 5.33 \\
\hline$=1$ & 4.82 & 5.27 & 5.38 & 4.70 & 4.69 & 4.88 & 4.83 \\
\hline
\end{tabular}

The table reports a comparison between the equilibrium value of a given variable when Home offers an $8.7 \%$ ad-valorem subsidy to total sales to firms with an export intensity of at least $70 \%$ relative to laissez-faire. 